An-
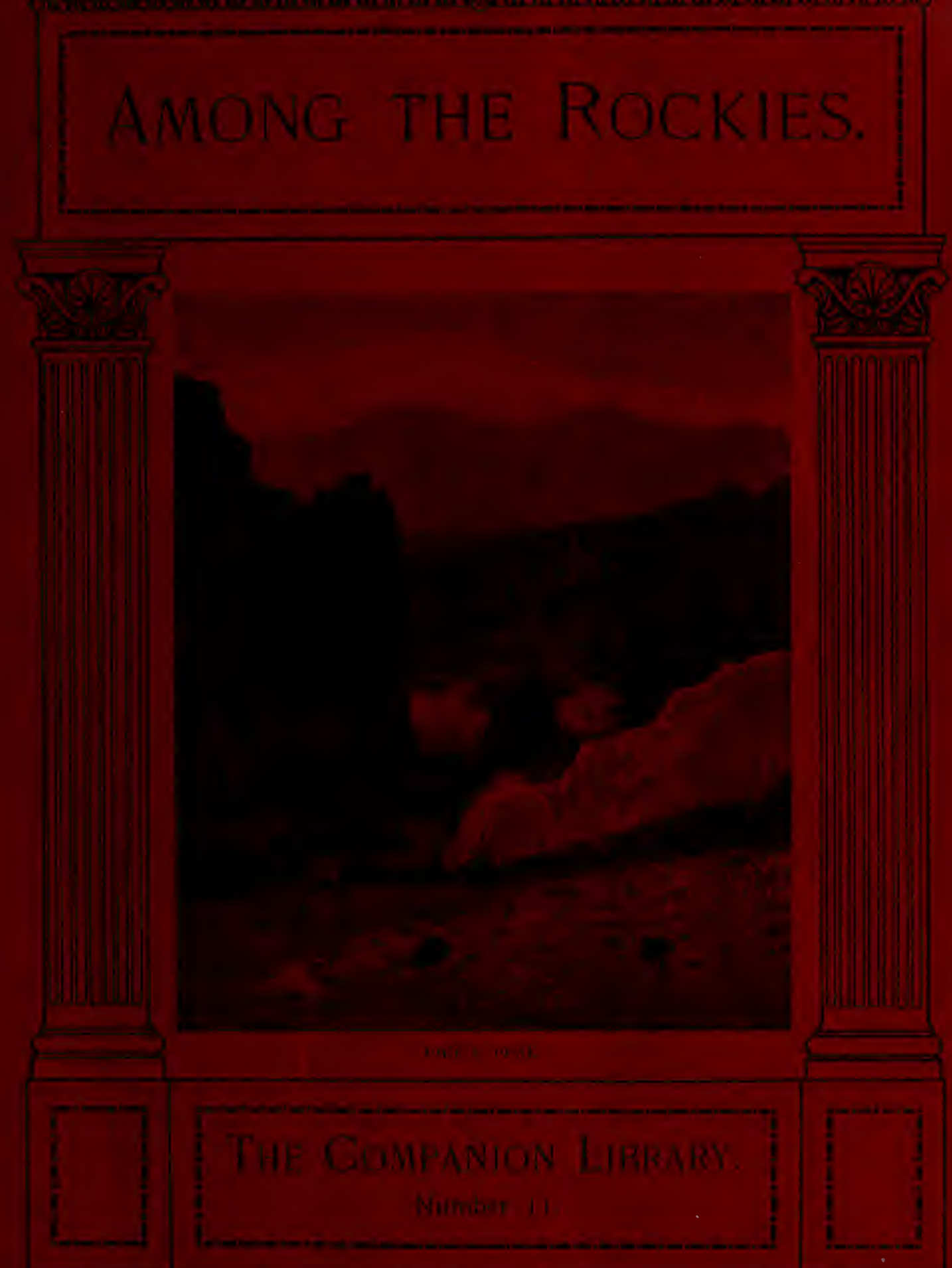

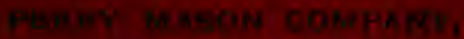

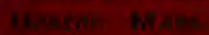




\section{THE COMPANION LIBRARY}

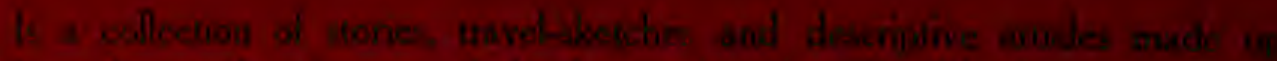

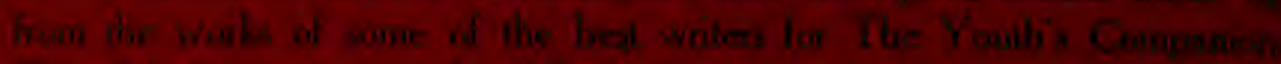

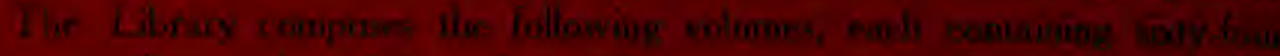

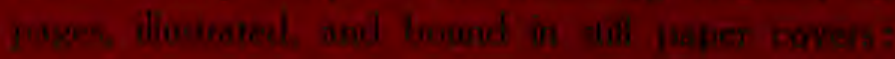

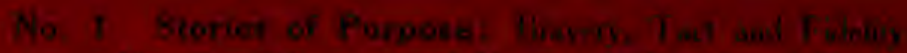

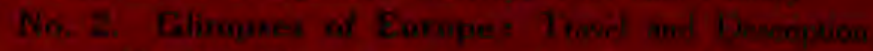

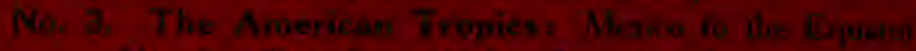

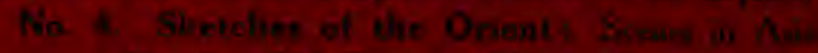

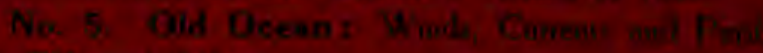

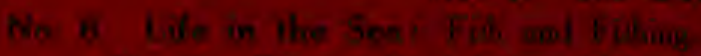

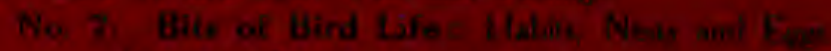

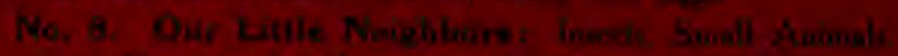

Fin. 9. Ar Howe in eds Forest. Mul knowel

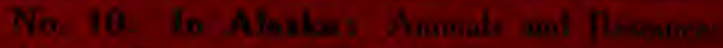

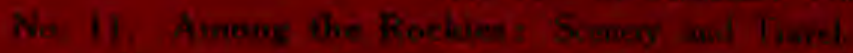

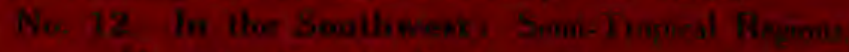

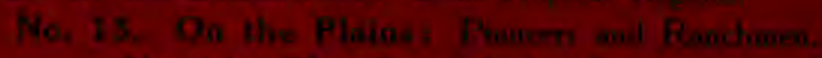

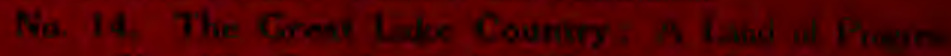

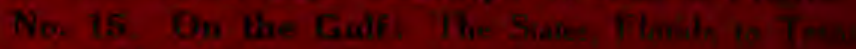

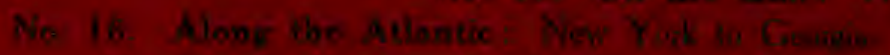

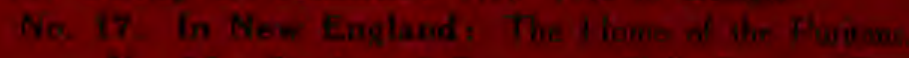

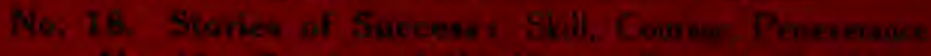

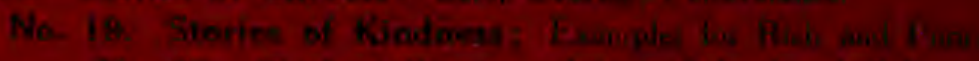

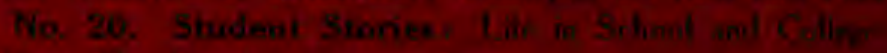

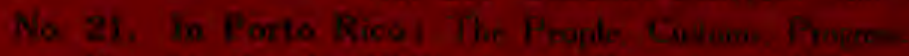

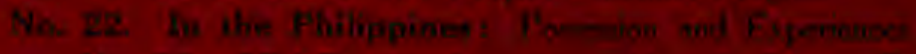

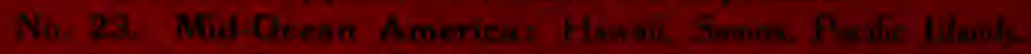

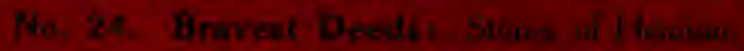

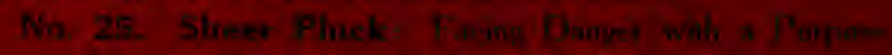

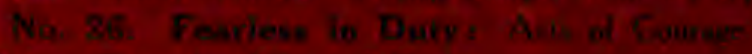

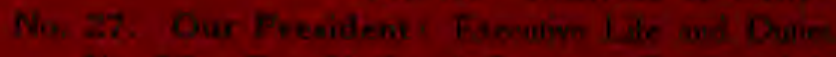

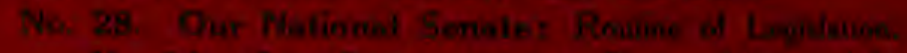

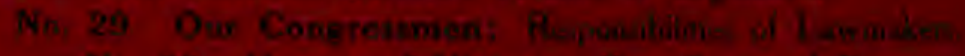

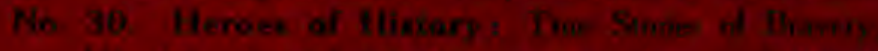

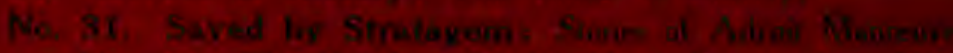

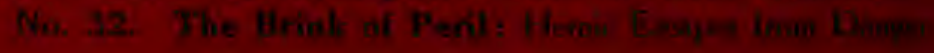

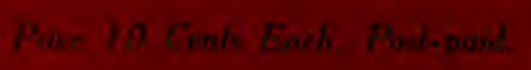

\section{PEREY MAGON ROMPNNY Palifiers}

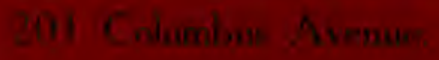

POETION, MLSA 


\section{SELECTIONS}

FROM

\section{The Youth's Companion \\ FOR}

SUPPLEMENTARY READING.

Number 11.

\section{AMONG THE ROCKIES.}

CONTENTS.

PAGE

THE BIGHORN CAÑON

GEN. JAMES S. BRISBIN, U. S. A. 3 HUNTING ELK ON SKEES SHERWOOD DAVIS. 9 VISITING THE YELLOWSTONE PARK GEORGE S. ANDERSON, U. S. A. I4 IN THE YELLOWSTONE PARK C. A. STEPHENS. I6 ROCKY MOUNTAIN BURROS . . J. H. LEWIS. 22 CHINESE RAILWAY LABORERS • • • . ERNEST INGERSOLL. 26 SOME ROCKY MOUNTAIN ANIMALS . . PROF. ARTHUR LAKES. 32 WHERE RAILROADS GO . J. L. HARBOUR. $3^{8}$ DIGGING UP A FOSSIL MONSTER - . PROF. ARTHUR LAKES. 42 A PETRIFIED BIG TREE . . . • . PROF. ARTHUR LAKES. 48 THE HOLY CROSS AND TWIN LAKES . . . . J. L. HARBOUR. 53 SIGNAL STATION ON PIKE'S PEAK • . . . . J. H. SMITH. 57 


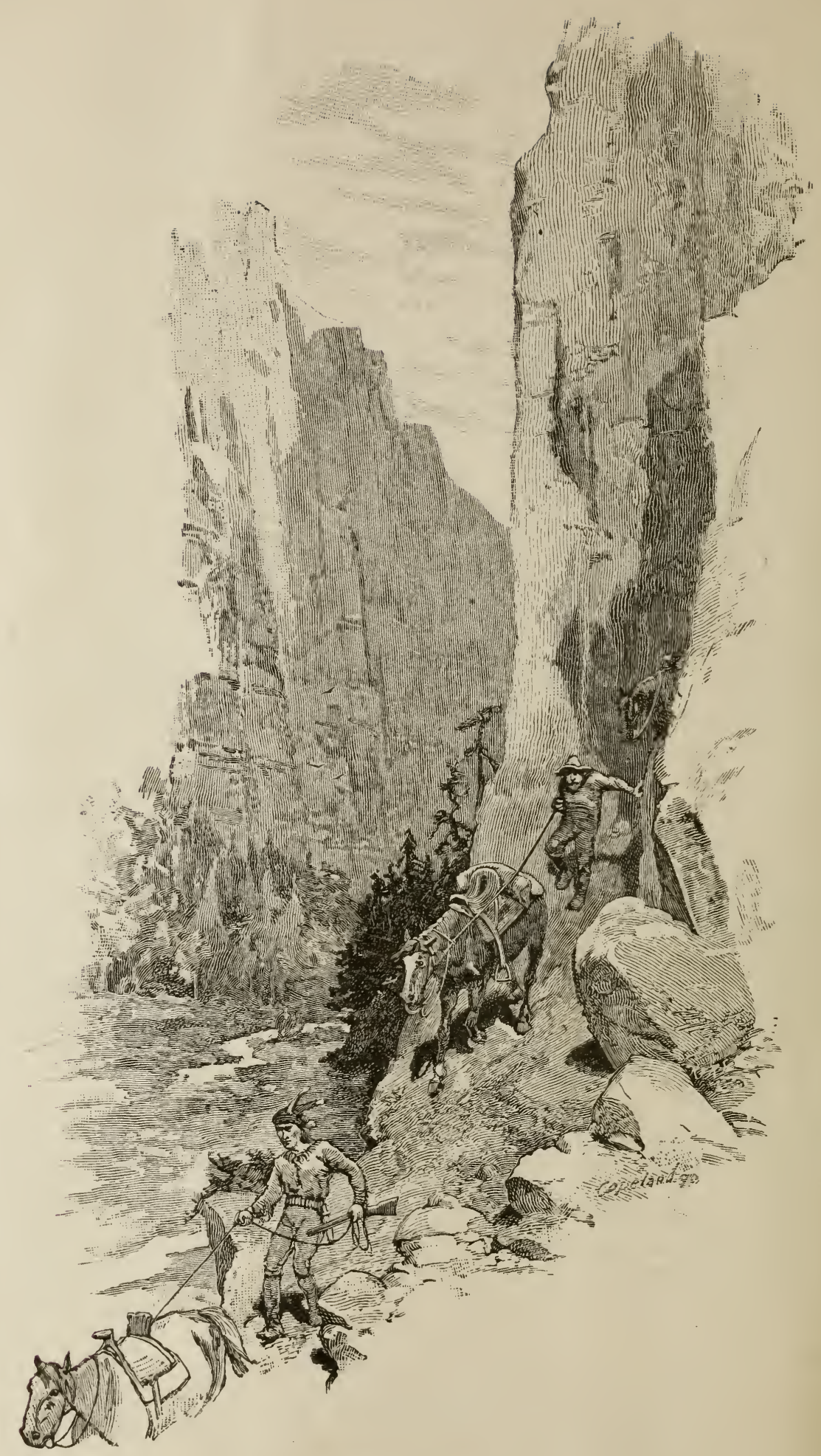

The Bighorn Canon. 


\section{The Bighorn Cañon.}

Though the Bighorn Canon is located within sixty miles of Fort Custer, in Montana, where I am writing, I can find no one who has ever been through it. Some men have been in it, but did not stay long, and only a few have traversed it for as much as twenty miles.

The only man I ever met on these plains who could give a good account of the great canon was Lieut. George P. Belden, the celebrated trapper, guide and scout, who died some years ago. Even old and thoroughly travelled scouts and hunters have had to acknowledge that they knew nothing about the Bighorn Canon.

Belden often told me about it, and said he had been from its mouth to the top, and once had spent a portion of the winter beneath the friendly shelter of its mighty walls. Belden left some notes in a book giving a partial account of the sunken plain, as he called it.

"We had been toiling up, up, all day long," says Belden in these notes, "and at night looked far back and below us to the Chetish or Wolf Mountains. They were to the north, and fully forty miles distant. They loomed up from the plain, low, broad, black and flat, and we could see that they had no connection at any point with the giant Bighorn Range. West of us was the Bighorn Valley proper.

"Wishing to strike the Bighorn Canon at its mouth and go up it to its head, I told our Indian guide so to lead as to bring us to the canon at its junction with the river.

"Early the next morning we set out nearly due westward. Our Indian guide, although a Crow, and born in the country, had great difficulty in locating the canon, so broken and uneven was the land. At last he pointed to some pines on a distant hilltop, and calling out, 'There! there!' rode smartly forward. 
"At the foot of the mountain below the pines we found an old trail, almost obliterated from long disuse. Taking this the guide galloped swiftly forward.

"In about an hour he stopped on the brink of a deep ravine, and told us that this was the great canon. Dismounting, and going forward on foot, I looked over a wall of rock hundreds of feet high. The Indian said that a mile below was a trail leading down into the canon, and that we could descend if we wished. He said it was twenty miles or more to the mouth of the canon, and the descent -was more difficult there than by the trail just below us.

"I told him to go ahead, and we would enter the valley at once.

"After rolling, jerking, sliding and tumbling, as it were, down the side of the canon we suddenly found ourselves in a little valley, from which the light was almost excluded by the black walls of rock.

"There was a bright streak of sunshine along the centre of the valley, and a stream rippled by. The tall pines sighed mournfully in the light breeze. Not even the tops of the tallest trees ascended as high as the top of the canon. They were extremely tall, for they had been sheltered from the storms that had twisted and dwarfed their less fortunate neighbors on the prairie above.

"The little stream was filled with mountain trout. They were of the mountain brook species, and we could see their golden bars flash as they darted through the crystal waters.

"Up the stream was a herd of a dozen elk, and below, almost within rifle-shot, two black-tailed deer browsed. There were many kinds of birds, and the cawing of hundreds of crows could be heard up the stream where the timber was thickest.

"When the sounds of the birds, the brook and the trees ceased, the silence was intense. The valley seemed cut off from the rest of the world.

"One has strange feelings in such a place; and I was not 
sorry when the Indian, who had been creeping down the valley toward the deer, fired a shot and killed the buck. The noise of his gun seemed almost as loud as a cannon, and as the echoes reverberated far up and down the valley, the birds rose screaming in the air, and circled far above us.

"Supping on trout and deer meat, we passed the night by the side of the stream.

"Next morning, wishing to hunt, I set out with a companion, our rifles on our shoulders, leaving the guide and scout to pack and follow with the camp at their leisure.

"As we trudged along, many prairie-hens flew up. The whirring of their wings and the loud call of the old cocks attracted the attention of a fine buck. On seeing us, he stooped low, and creeping away, hid in the nearest bunch of pines. He seemed to suppose that we had not seen him; and Dan, my companion, laughed outright to see him tiptoe into the wood.

"A mile farther up, as we turned a sharp angle of the high wall on our right, we saw a band of over one hundred elk grazing within easy rifle-range. The leader threw up his head, whistled danger, and started up the valley.

"The excitement was too much for old Dan. Bringing his gun to his shoulder he fired, and the leader fell, shot through both fore-shoulders.

" The herd halted when the leader fell and gathered about him. None except the wounded buck had yet seen us. They looked everywhere about in a frightened way, but we had hidden among the rocks. Finally they started up the valley again. It was a beautiful sight. Nothing but a mass of horns, tips of ears and flying feet could be seen as they moved in a compact mass. The noise of their hoofs and the glint of their red necks reminded us of a flight of birds more than of animals.

"The Indian guide said the true name of this canon was Elk Canon, and that elk were always to be found there in great numbers, not only on account of the fine shelter it 
afforded, but of the warmth and good grass and water. After looking at the buck, now quite dead, and taking his hump and tongue, we pushed on up the valley in the rear of the elk.

"We soon began to notice that both the canon and the stream were becoming narrower rapidly. The stream was a mere rivulet, but still well stocked with red speckled trout. The valley was so narrow that no animal could pass up or down without coming in close rifle-range. The wall rock on either hand became higher and higher. Little springs from

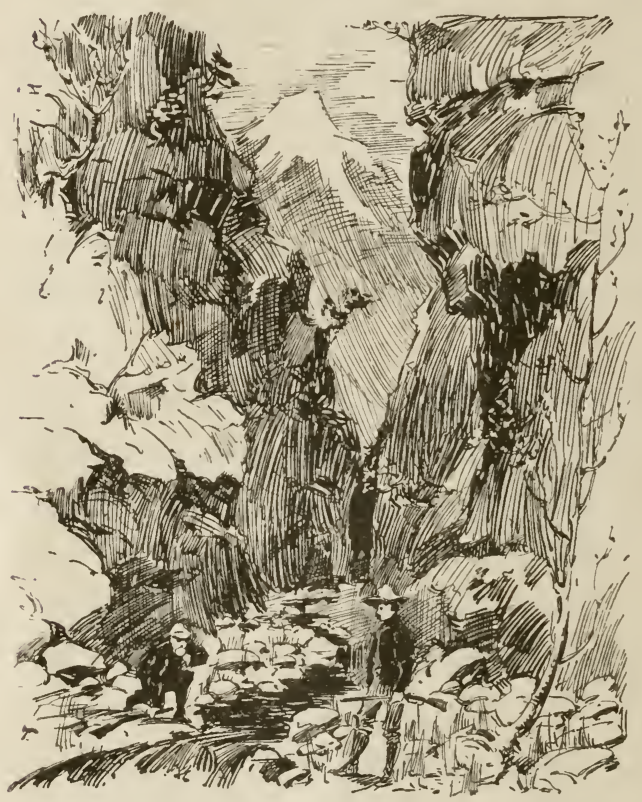

The Narrow Valley. the side flowed in and bubbled up from the base of the high walls. Pockets, meadows, thickets and ravines increased in numbers, and the great hanging walls above our heads closed until the daylight was almost excluded. Deer were very abundant, but all other game had disappeared.

"Selecting one of the widest of the little pockets or side valleys, we began to climb a deer trail leading up the mountainside.

" Since we left camp we had travelled due east, and now we went up the south side of the wall, and soon found ourselves in the wildest of scenery.

"On our right was the snow range, with glistening tops flashing like polished silver. The valley had been very warm, but the change to a colder temperature was perceptible at an elevation of five hundred feet. We were going out of summer into winter, and all within a mile or two.

"The air became so thin that one could not run at all, and every few hundred steps our breath gave out, and a 
short rest was necessary. We were entering the confines of perpetual winter.

"Working forward over the snow line, we found the stunted old pine-trees becoming more arrd more gnarled, and most of them dead or dying. Here and there, in the crevice of a rock, we found a bush growing which bore brown berries that were sweet to the taste and not unpleasant eating.

"Here and there little red and striped chipmunks frisked about, and shot in and out of the rocks. They seemed larger than the chipmunks of the East, but were evidently the same animal. We also saw several large rock-rats, or mountain squirrels, which inhabit these high regions. Some of them were as large as small prairie-dogs, and were like them except in their movements.

"These animals are sluggish, and shooting at them does not seem to alarm them in the least. They drag themselves lazily in and out of their holes and act as if they were deaf.

"Above the ground-vines rise ranges of granite rock, gray, pink and brown, with veins of delicate purple and blue running through them. There is a rose-colored granite on these mountains that takes a high polish and is very beautiful. I saw an almost jet black marble, the finest stone I had ever seen, and there is much white marble.

"From the top of these granite walls the snow extended over the mountain, hiding everything above from view.

"Standing at the foot of the great granite walls, our feet pressing the snows of many winters, our teeth chattering in the cold mountain air, we looked far down below us to see the Black Canon with its green trees, grassy valley and sparkling stream, which looked like a tiny thread of silver.

"With my glass I could see wild sheep on the opposite hills, and far down the canon a band of deer playing at hideand-seek as they dashed in and out of the little thickets.

"I had been at the snow-line before, but never at so 
interesting a place as the Black Canon. Finding the night coming on we began our downward course.

"About half-way down the mountainside, as we came out from among à group of pines, we noticed a large mound, upon which sparkled millions of bright little objects, having the appearance of bits of broken window-glass. The mound, we found upon approaching it, was a bed of gypsum; the thin scales and large slabs gave it the appearance of a huge jewel set in the mountainside.

"Down, down we went, almost an hour and a half, and then we came out into the little valley once more, and found our escort awaiting us. The sun was still shining on the hills, and we determined to go up the canon a little way and camp for the night.

"An hour's march brought us to the head of the stream and some fine springs. Here, the guide informed us, we must stop or go a long way to water. We accordingly encamped, and after a good supper went out and gathered bearberry leaves, to mix with our tobacco.

"We found many curious colored pebbles, some agates and several other stones of value.

"We had explored only twenty miles of the middle portion of the great canon, and in the morning determined to climb out and go over to Bear Canon of the Bighorn to hunt for grizzlies."

This is the only description of the Black Canon of the Bighorn that I have ever seen. It is meagre and unsatisfactory, but I hope to explore, map and photograph the entire region.

Gen. James S. Brisbin. 


\section{Hunting Elk on Skees.}

Of all the pleasures which have fallen to the lot of an amateur photographer with a taste for wild life and the making of pictures of big game in its native state, probably the keenest befell a young amateur whom we may call James Brackett, for want of authority to use his real name.

Being in the Flathead country, in Montana, he was invited to join a party of hunters who were going out into the Rocky Mountains to take live elk with lasso and skees. He accepted the invitation; he had been accustomed to travel on skees in taking winter views. But instead of a lasso he himself carried his camera and a large revolver for emergencies.

At Columbia Falls, Montana, north of Flathead Lake, young Brackett joined the two hunters. They camped in the hills and started out before daybreak up the mountain. There was to be a long ascent before the sport began, for the skee-hunters can take their game in this way only when they have the advantage of descent upon them.

The skees used by the party were made of birch, and were eight feet long, four inches wide, and about half an inch thick. They were strapped to the feet, and the front ends were slightly curved upward.

The two hunters carried no rifles. Each had at his belt a strong lasso, sixty feet long, and a hand-axe, or large and very sharp hatchet. Their hunting was to include no slaughter, and they needed no weapons except revolvers and knives, for use in case of chance unsought encounters with pumas or bears. They carried also a liberal lunch.

Though he knew how to walk on skees, Brackett found the ascent of the mountain on them, over the deep snow, an extremely hard task, especially when he had to keep pace with these practised and hardened hunters. Two or three times he was on the point of giving it up, but the hunters 
good-naturedly paused to let him get his breath, though they had no time to lose.

Toward noon the hunters declared that they had ascended far enough. They had already found signs of elk, and knew where to look for them on their descent. Here they lunched, saving some of their food for the unlucky emergency of a failure to get back to camp for the night. Then the rapid descent was begun. 'The hunters' eyes commanded a great sweep of the mountainside,

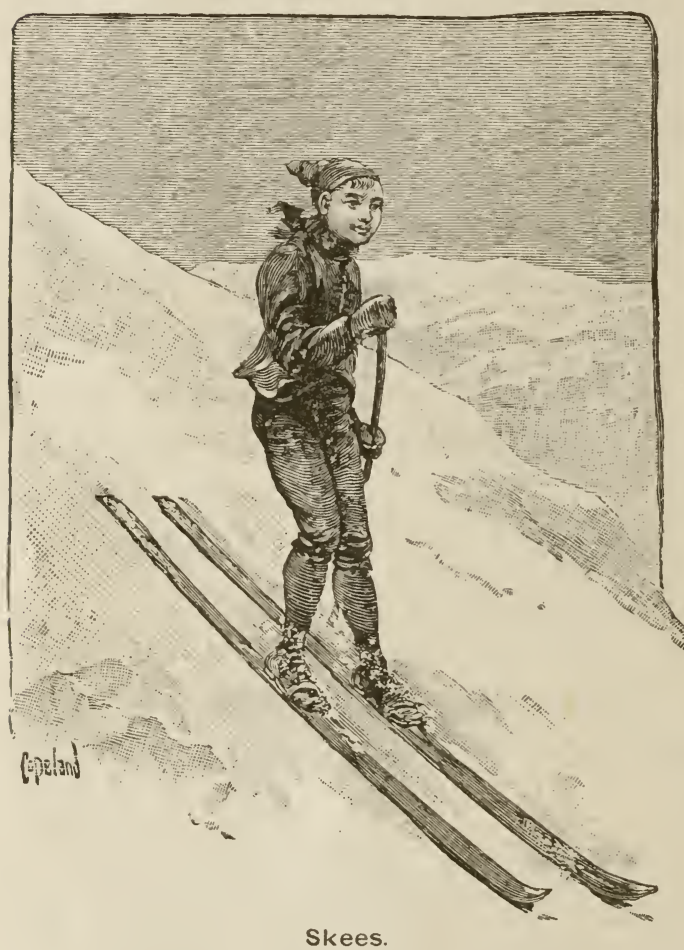

Skees. nor did they neglect the details of thickets and ledges. It was a wild and craggy spot-precisely the ground which the Rocky Mountain elk seems to enjoy.

As the three men were swiftly but watchfully descending on their skees, Brackett finding it quite easy now to keep up with the hunters, the latter paused, put their fingers to their hips and loosened their lassos. It was evident that they had caught sight or wind of game. Brackett saw no living creature, but he nevertheless unlimbered his camera. Before them lay a sharp and smooth declivity, glittering under the midday sun.

Here and there rocks cropped up, but for the most part the space was clear. All at once, far below, Brackett saw an animal shoot out into view from behind a crag, apparently, though the creature had all the time been in front of the crag. The unpractised eye of the photographer had not made him out, so closely did the yellowish-brown of the elk's body 
and the white of his rump approximate the color of the rock and snow.

"Goodness!" Brackett could not help exclaiming, "you're not going to try to get game so far away as that?"

For answer the two hunters shot down the mountain, their lasso coils held in their left hands, the noose in their right both hands in front of them, their knees and bodies gracefully bent. They presented so fine a sight that Brackett took a shot at them on the spot; and by the time he had closed his camera and was ready to start after them, they seemed to be half a mile down the mountain! He gave up all attempt to overtake them or to get a shot at their operations with the elk, but contented himself with the picture he had already taken of their seeming drop into space, and with keeping them in view.

Meantime the elk was off in a series of tremendous bounds; but his course lay almost laterally along the side of the mountain, while the two hunters, going at a speed which could hardly be less than his, were heading him off by a flanking movement. Every second

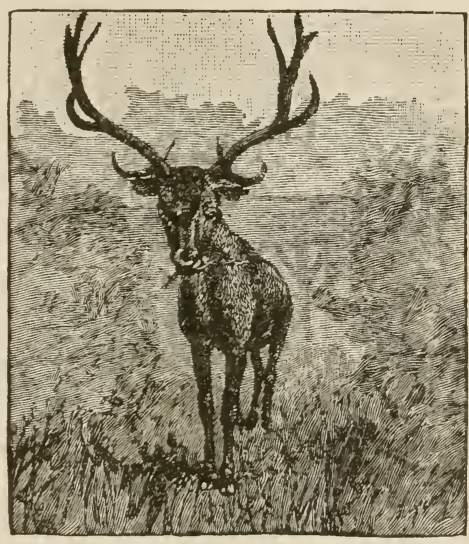

EIk.

brought them nearer together. At last the elk, which Brackett thought was the largest horned animal he had ever seen, seemed to realize that he was being headed off.

He turned sharply and plunged straight down the mountainside. Brackett heard the two hunters shout to each other; they swerved apart in such a way that the plunging animal appeared between them in Brackett's line of vision. Then he dropped quite out of sight over a ledge, beyond which Brackett saw nothing but blue sky.

The two hunters plunged straight on, and the young 
photographer gasped, for it seemed to him that they were whirling to certain death over a precipice. But meantime he was himself advancing at an extremely swift rate of speed; and his path presently brought into view a bench of the mountain below the ledge.

Over it the two men went. The elk came into view again, plunging heavily in deep snow. The hunters, one on each side, came up with him. Without a word or sound, the man on the right cast his lasso; it fell over the great animal's horns, and was instantly drawn taut.

And now began a strange chase, comparable to that of a whale at sea into which a harpoon has been thrown. The

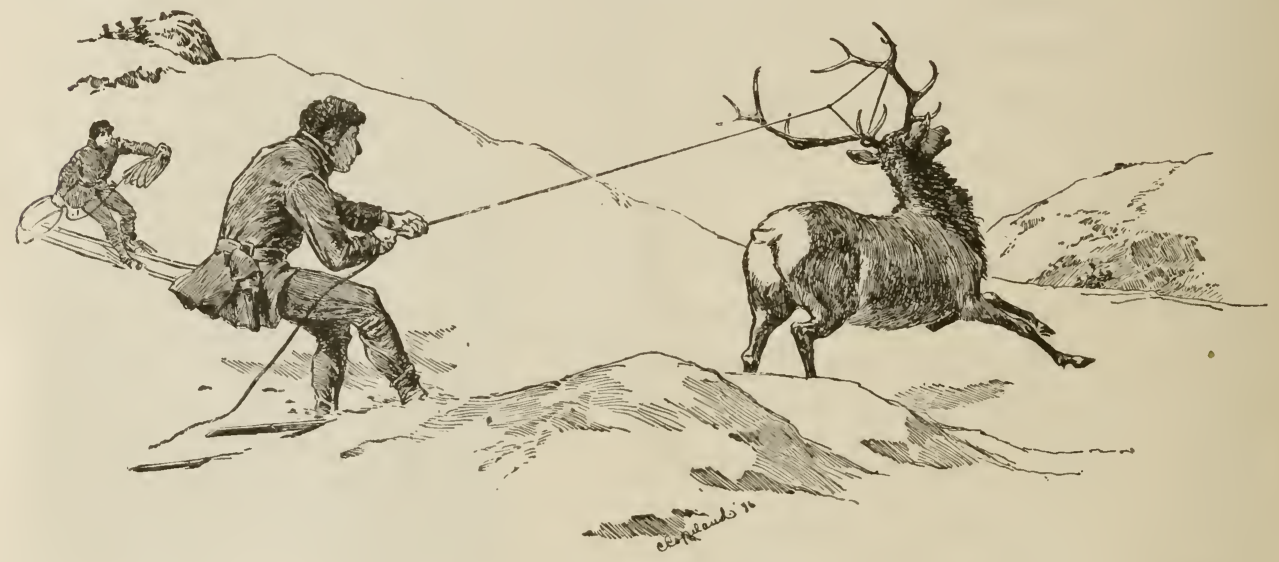

Capturing an Elk.

second man could have thrown a lasso from the other side, but both men could not possibly have held the elk on this descent, which presented neither tree nor jutting crag, and where now the creature seemed to have found firmer foothold. Away he went, still down the mountain; the man who had roped him clung to the line, allowing himself to be drawn, the snow flying from his skees. The other man made his best speed, but was being left behind.

The elk was plainly headed for a thicket of pines some distance below. He followed his instinct in this, and he also did the worst possible thing for himself. It was what the two 
hunters most desired. On he went, and in less than a minute had plunged among the trees, and in an instant more was struggling in the snow, for the hunter had snubbed his line around a tree and had the creature fast. He might, however, have inflicted some injury upon himself if the other hunter, coming up, had not thrown his lasso from the other side and snubbed him to another tree. He was now completely at the mercy of the men.

Brackett came up and with his camera took a shot at the elk, which had given up its struggles. The hunt was over for the day, for it was necessary to go down to the camp and bring up the dog-sledge, on which to transport the captured elk to Columbia Falls. Brackett and one of the hunters remained on guard to protect the elk, now bound firmly with one of the ropes, from the visits of unscrupulous wolves and pumas, which would not have hesitated to take advantage of his situation if he had been left alone. The elk turned out to weigh nine hundred pounds, and was the most magnificent specimen taken for several years.

Brackett remained two weeks with the hunters. In that time they took but two more elk - for they had had remarkably good luck to come upon their game so soon and so successfully on the first day. All of their captives were taken to the ranch of a gentleman farther down the mountain, who has fenced in a considerable space for the purpose of testing the question whether the elk cannot be domesticated and made to draw loads, as the reindeer does. This gentleman already has a well-broken elk team, which he has driven about quite freely.

The animals in his possession appear perfectly tame and gentle. Whether or not the American elk has any value for draught purposes remains, however, still to be proved.

SHERWOOD DAVIS. 


\section{Visiting the Yellowstone Park.}

The Yellowstone Park, larger than the State of Connecticut, contains, perhaps, more natural wonders than any other tract of equal area: the exquisite deposits of the boiling springs; the geysers, spouting water two hundred feet in the air; the canon, most beautiful and grand; the many waterfalls of rare loveliness; the immense lake of unfathomed depth, eight thousand feet above the sea, surrounded by mountain-peaks covered with perpetual snow. But one should not suppose, as some people do, that it is wholly a land of marvels, for it presents many spaces of the most quiet and lovely scenery.

It is seldom possible to enter the park before the first of June. In 1893 the lake ice did not break up until the nineteenth of that month, and wheeled vehicles could not pass from the Upper Basin to the lake until the twenty-second. This was a very late season, but such may occur again.

In July there are flies, gnats and mosquitoes,- great nuisances, to be sure,- but the nights are cold and the insects vanish early in the evening, while many other conditions are favorable. The earth is then covered with lovely wild flowers; the watercourses are running full, and their falls are at their best; the fishing is then extraordinarily good.

In August the mosquitoes and their kin have disappeared, and there are no troublesome rains ; but the lovely flowers are then no longer at their best; dust has replaced mud, and the fish are not so eager to take the fly.

September presents a constantly lessening list of attractions ; fewer flowers, less water in the streams, fewer fish, less chance of seeing large game, more dust and colder nights. Moreover, the summer travellers have then littered the favored camping spots with their unsightly leavings.

July, then, is the best month, but a start the last of June 
would be advantageous, particularly if the season opened early.

A proper outfit of clothing is highly important. As the days are generally hot and the nights very cold, thick underflannels are recommended. No overcoat is needed except a mackintosh, which is very desirable. Brown or drab clothing is most satisfactory.

As to the length of time and the amount of money required for the visit, that depends on whether the party means to glance at the tract or see it thoroughly. Cinnabar, the terminus of a branch of the National Park Railroad, is the point of entrance to the park.

Regular tourists who put up at the park hotels spend six days in the tour. A camping trip might be made in that time, but a month can be profitably devoted to it. The regular circuit could be made slowly and on horseback in about twelve days ; then there would be side trips off the main roads, fishing excursions and numerous desirable delays that would well occupy the entire month.

The details of the trip must of course depend on the time allotted to it. A week used in going down to Jackson's Lake, and a week or ten days in a visit to the wonderful hoodoo country, would amply repay for the time and money spent.

Hunting trips are often outfitted here, but all the hunting must be done outside the park. The thorough protection of the game within the park has made it a reservoir from which all the surrounding country has been fed, so that now this region is the best hunting-ground in America.

GEORGE S. Anderson, U. S. A. 


\section{In the Yellowstone Park.}

When you go to the Yellowstone Park, certain notices giving forcible hints as to your conduct will present themselves to your eye from sign-boards nailed to the trees. They are of this sort:

\section{EXTINGUish YOUR Fires. \\ No Shooting. \\ GATHER NO SPECIMENS.}

Do Not DEFACE THE Formations.

These are all very proper and necessary; and the penalty for disobedience may be a dusty walk out of the park, with a soldier behind you. It may involve the confiscation of your luggage, or even heavy fines and imprisonment if the offence is a grave one. No shooting is allowed, except in defence of one's life, and as a consequence of this wise restriction game in the National Park is becoming not only delightfully plenty, but unusually tame.

The ducks sit, quacking quietly, in the little lakes, as the stage-coaches rattle close past them. Squirrels actually have been known to run up men's trousers' legs, and deer are increasing in numbers. It is said that the herd of two hundred buffalo about the Yellowstone Lake show signs of increased confidence in man.

Unusual vigilance will be practised by the park superintendent to protect this bison herd, and if nature would but kindly endow the poor beasts with instinct to remain in the park, this last remnant of a once mighty race might survive here for centuries, to remind future generations of the countless herds which once roamed over the entire West.

Another and less pleasing result of prohibition of shooting is the multiplication of bears. Black bears, silver-tip bears, cinnamon bears and roach-back bears are found in the park 
in greatly increased numbers, and some shooting may have to be done to keep these creatures within proper limits.

This wise protection of life makes the park a paradise for the smaller birds which naturally inhabit such regions. The beautiful valley of the Yellowstone may become the happy

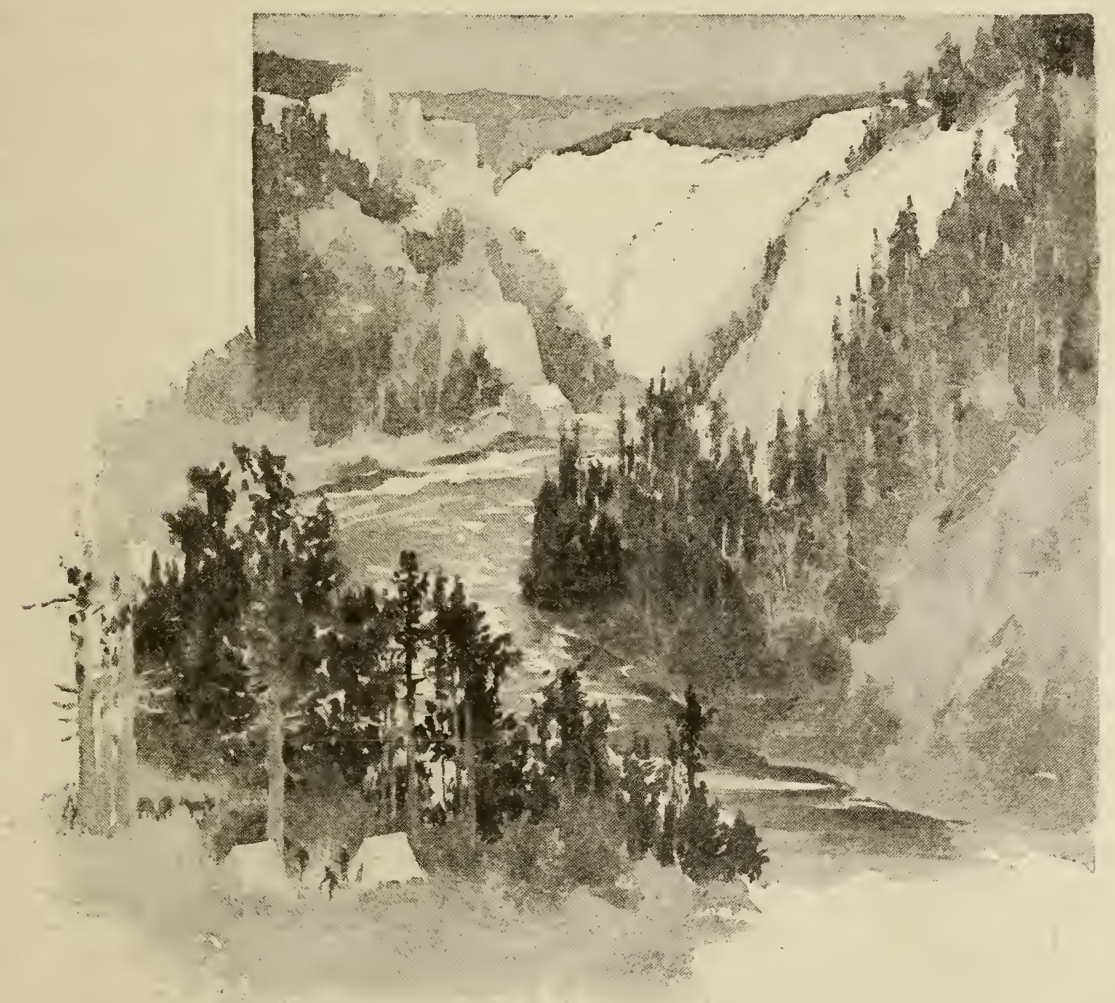

The Yellowstone Valley.

refuge of the songsters which the ruthless fowlers have driven to the companionship of the bison.

One privilege is granted to the sportsman. He may find as satisfactory fishing in the park as in any other region frequented by tourists. A hundred pounds of trout a day is no unusual catch for a single rod. That unusual fish, the grayling, is also found in the park, in the Madison River. 
But another prohibition is necessary, and tourists may some time find a strange notice like this:

Do Not SOAP THE GEySERS.

To soap a geyser is a very naughty act; and for that reason, perhaps, many tourists seem strongly tempted to transgress in this manner.

An alkali dropped into the bowl of a geyser will frequently cause it to act at once, and in a particularly frantic manner; and as certain of the geysers are somewhat tardy in exhibiting their spouting powers, -it is a temptation to many young people, and to a few older ones, to drop a cake of soap into the steaming bowl. Geysers, like human beings, have a certain quite definitely limited lifetime. They do not go on forever by any means. The pipe, or tube through which the hot water and steam are ejected, the bowl, the caldron, and the steam-chambers deep underground, have a well-marked period of growth and decline.

The apparatus, by means of deposits from the hot water, first increases in symmetry, form and efficiency as a spouter; then it gradually falls out of order and subsides into an inactive hot spring. It can be said that a geyser is good for only a limited number of spouting performances, through a certain number of years, or decades.

The geysers of the National Park vary much in their hours for spouting. Old Faithful spouts every hour, with great regularity, and will probably be a short-lived geyser compared with the Beehive, which discharges once in twenty-four hours ; the Giant, which is in action once in four days; the Giantess, which only favors the public with a performance once a fortnight; the Lion, which rouses into activity and roars after long, uncertain intervals; or even the Splendid, which sends up its beautiful column of steaming water and spray to a height of two hundred feet once in three hours.

Manifestly it is in the interest of the general public to have these grand and wonderful exhibitions of subterranean energy 
endure as long as possible. It should not be beneath the dignity of any tourist to wait patiently the normal time of their grand displays. To cause a geyser to burst forth suddenly by artificial means is to shorten its life, and hence to prevent future tourists from enjoying it.

But many inconsiderate tourists go to the geysers with cakes of soap in their pockets. Hence the government has found it necessary to station a squad of soldiers in close proximity to the geysers, to protect them from the saponaceously inclined sightseers.

The Beehive Geyser is one of those which appear to be especially sensitive to soap. The rogue who drops soap into the Beehive barely has time to retire to a safe distance before the performance begins, and it really seems as if the spouting, foaming, frothing geyser would turn itself wrong side out in its efforts to be rid of the obnoxious alkali.

Our party of eight was a very law-abiding one. We had often said to one another that it was an exceedingly mean trick to put soap into a geyser, or to attempt, as some previous visitors had evidently done, to stir up the way-down stomachs of the fountains - particularly the old, retired ones - with long poles. Such vandalism we all denounced as disgraceful.

Nevertheless a strange thing happened. On the front seat of our stage-coach rode two youths, fresh from college.

On our arrival at the Upper Basin we learned that the Beehive, so called from the shape of its cone, would not spout until the following morning, and the Splendid not much before nightfall. But after watching a grand performance by Old Faithful, we all went out to see the bowls of the other geysers.

In the course of our walk, we crossed the little Fire-Hole River, and after examining the pretty, hollow cone of the Beehive, went up to the Lion and Cubs.

Presently, missing our two young friends, we looked back and saw them still hanging over the Beehive cone, apparently gazing into the funnel of the fountain. 

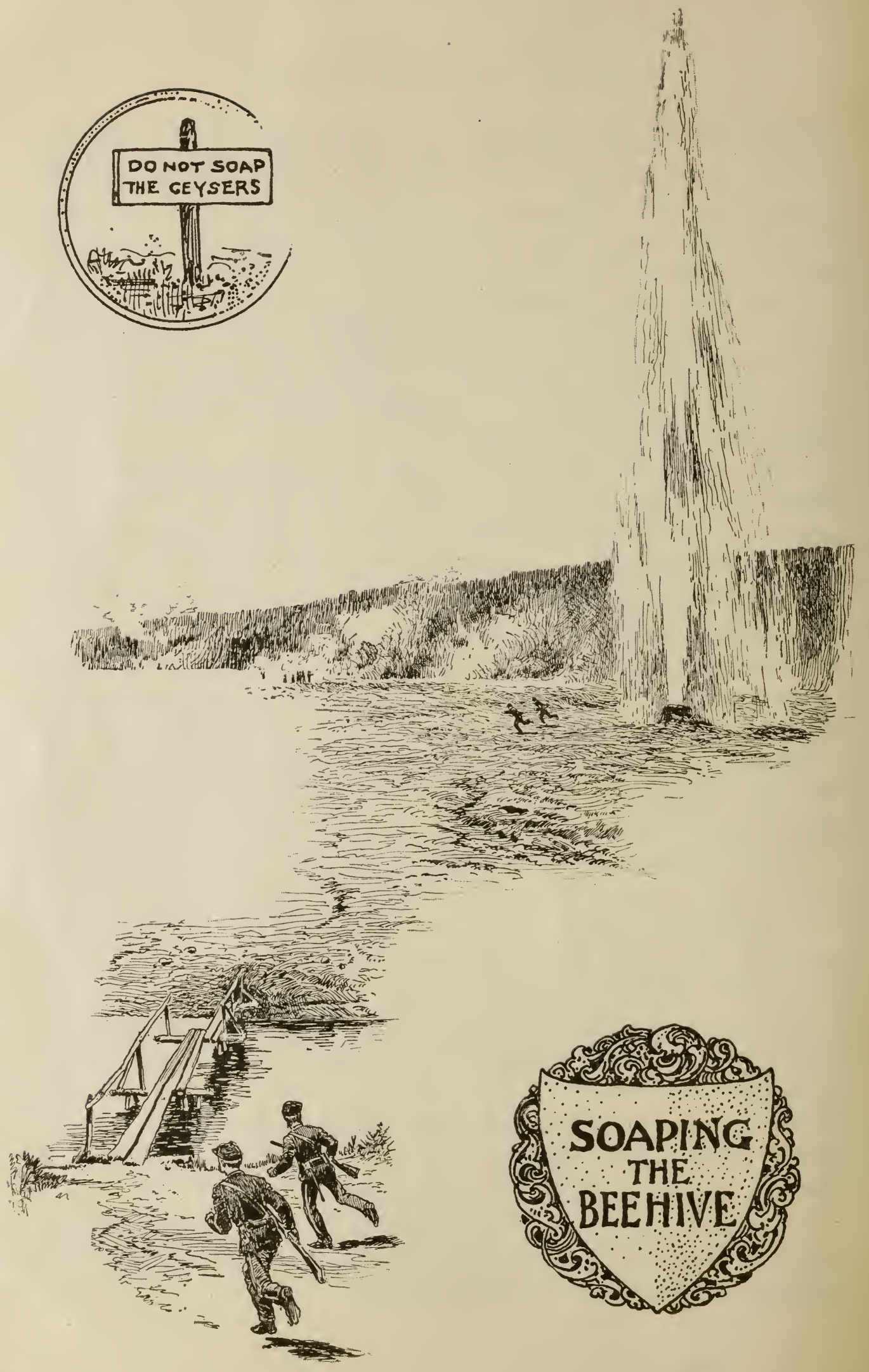
Within less than a minute afterward we heard a shout, and saw our young fellow-tourists running away; and immediately the Beehive went off, favoring us with a tremendous display.

Jets of water played to a height of two hundred and fifty feet. The roaring and frothing were frightful. The earth far around pulsated and trembled.

It seemed to me that the geyser would burst and go to pieces. Its extraordinary upheaval continued for some minutes.

Meantime a considerable crowd collected, and two soldiers came hurrying to the spot. As soon as the eruption had subsided the soldiers examined the steaming ground about the cone, and picked up several pieces of pink soap. This circumstance, joined with the fact that the Beehive had spouted out of season, aroused the suspicions of the military.

They made inquiries regarding us, and ascertained at the hotel that five or six cakes of pink soap had disappeared from as many rooms since the arrival of our coach.

For a law-abiding party we felt extremely uncomfortable. There was no direct or positive evidence against any of our number, but none the less the sergeant in charge telegraphed the matter back to Mammoth Hot Springs. He appears to have mentioned specially our two friends; for on our return, three days later, they were waited or: very early by the young lieutenant in command, who put to them many polite but pointed questions as to their knowledge of the chemical action and reaction of alkalies.

They seemed to be extremely ignorant upon the subject. The lieutenant marvelled, but as there was no positive evidence against the young men, they were advised to read up in chemistry, so as to be able to pass a better examination the next time they came to the park.

C. A. STEPHENS. 


\section{Rocky Mountain Burros.}

Stupid, sleepy and slow-moving as he is, the Rocky Mountain donkey, or burro, has been an important factor in the development and growth of many mountainous districts in the West.

He has anticipated the service of the railroad train and the stage-coach in the transportation of freight and supplies to the most remote mountain camps. He is one of the most patient and faithful of all beasts of burden, although he is seldom promoted above the position of a common drudge.

His slowness and sureness of movement enable him to go up and over the loftiest mountain summits, around the sharpest, rockiest curves, on the narrowest of trails. $\mathrm{He}$ plods sleepily along at the very edge of the most frightful precipices without once losing his head, or making a single misstep. He goes fearlessly along where his bigger brother, the mule, could not go, and where his other relative, the horse, would not go if he could.

$\mathrm{He}$ is never skittish, his temperament is too phlegmatic for that. He is serenely indifferent to the things that affright the soberest horse.

At his very first sight of a locomotive under full headway, the donkey might prick up his ears slightly, and the sleepy look in his eyes might give way to one of mild curiosity ; but all the puffing and screeching it could do would not make him run away.

But this calm indifference is, I fear, more the result of stupidity than of courage.

The traveller to the remote mining camps of the West is likely to meet many burro trains going up long, steep and winding trails, heavily laden with merchandise of every kind, or coming down with bags of ore strapped to the animals' backs. 
It is surprising to see under what heavy burdens these little creatures can plod along. I have seen a family moving from one town or camp to another with all of their household goods on the back of a single burro, and these effects included a small cook-stove, a bedstead and bedding, two chairs, a grindstone and frame, and many pots, kettles, pans and

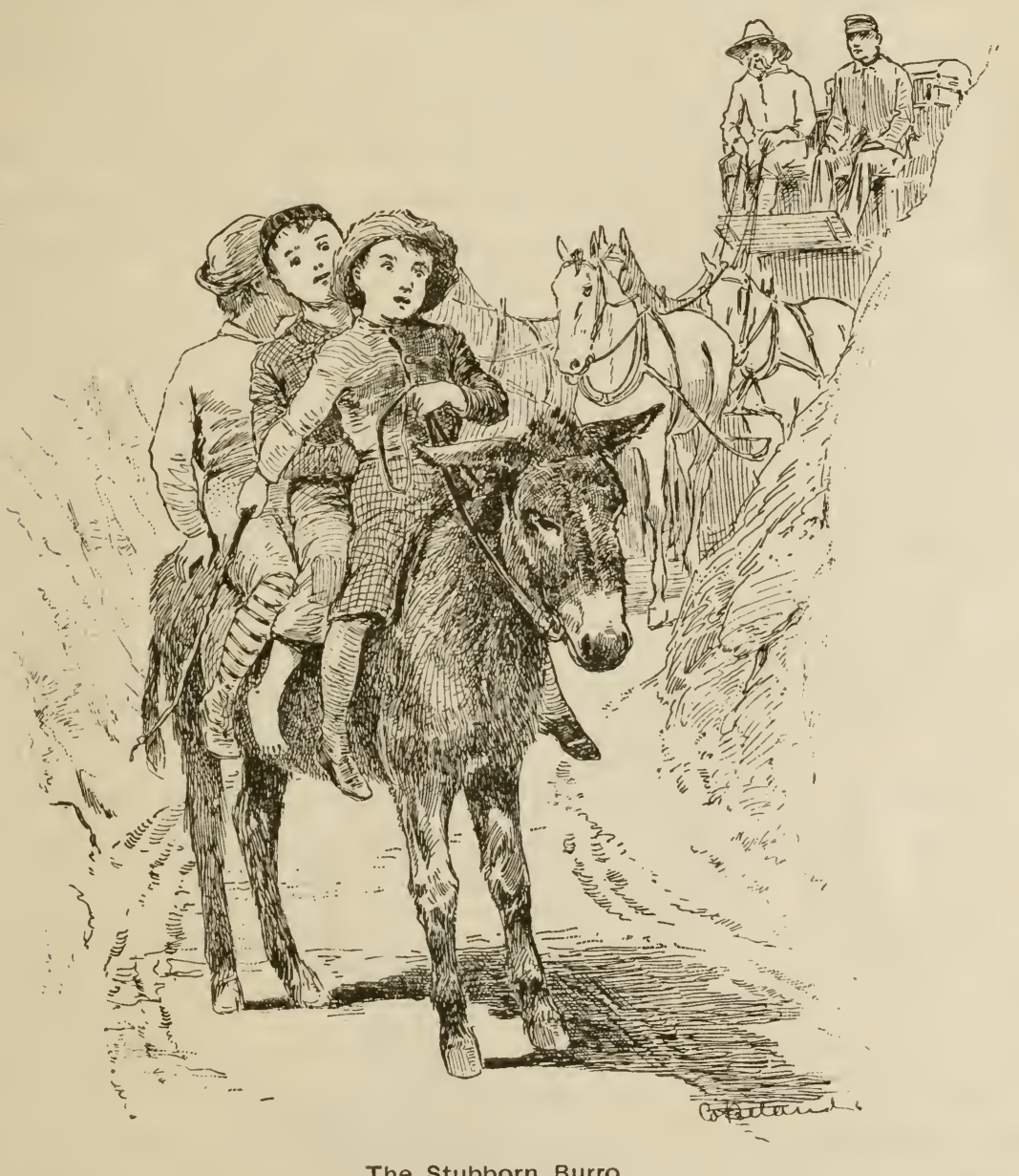

dishes. At the top of this prodigious pile was a baby, snugly and securely fastened to the mattress of the bed.

Thus heavily and clumsily burdened, the patient little donkey stepped meekly along, seemingly indifferent to the lowliness of his estate, or quite satisfied with it. 
Nothing but actual necessity ever induces the traveller, or any one else, to ride the burro from one place to another. 'The little animal's usefulness in this direction is greatly impaired by his diminutive size, and his unalterable determination never to go faster than a slow walk.

Indifferent alike to blows, kicks, threats and pleadings, he plods slowly along, even on the best of roads. His gait is so tedious that the man who mounts him is soon glad to dismount and go farther and faster on his own legs.

A tall man makes himself especially an object of ridicule when astride a burro. His feet barely escape the ground, and he is likely to hear many amusing but mortifying comparisons and remarks.

"How do you find the walking to-day?" is the ordinary satirical salutation to a long-legged man thus mounted.

Children, however, do not seem at all out of place on burro-back; and some of the Rocky Mountain boys and girls, with plenty of time for such modes of locomotion and childhood's capacity for enjoying it, find great pleasure in riding over mountain roads or the streets of mountain towns on the backs of these queer, stupidly submissive little animals.

"Shaggy" was the name given to a very small burro which was something of an anomaly among his kind. He was very black, with rough, shaggy hair like a bear. $\mathrm{He}$ was fleet of foot, tricky, treacherous and unwilling to work.

Shaggy belonged to a train of burros used in carrying freight to a mining camp fifty miles from a railroad. He did not have the sleepy eye of his mates; he had a sly, comical way of looking out of the corners of his eyes, and his driver declared that there were times when Shaggy "laughed right out loud."

He was always biting or kicking some of his mates, shying from the road, racing madly on ahead, or lagging lazily behind, or doing something else to bring upon himself the lash and the reproaches of his master. 
He made so much trouble, and his influence on the rest of the train was so demoralizing, that Shaggy was finally disowned by his master, and turned out to shift for himself in one of the gulches through which the train was passing.

The children of a miner living in the gulch adopted this incorrigible animal, and it is to be hoped that, under their gentler influences, he reformed at last.

Docile and sluggish as he commonly is, the burro rises to great heights of wrath and activity when engaged in battle with one of his own kind. Then his dull eyes flame, his ears lie back, all his shining teeth are revealed, his hoofs fly out and he fights valiantly.

These combats do not often occur, however. At other times the burro is one of the meekest and most faithful little burden-bearers in the world.

J. H. LEWIS.

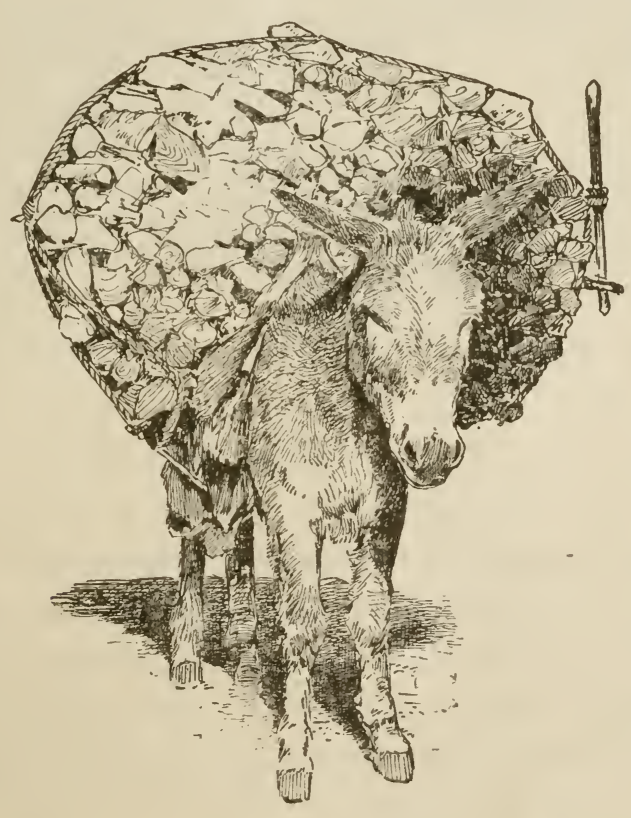




\section{Chinese Railway Laborers.}

During the years $1880-84$ the activity in railway-building in the northern part of the Pacific Slope was very great. Besides some lesser operations in Arizona, the Oregon Short Line, the Northern Pacific, the Oregon California, the Columbia Division of the Oregon Railway and Navigation Company's roads and the Canadian Pacific were all under construction.

There was great lack of laborers, and resort was had to the Chinese, without whom, indeed, those roads could never have been completed in the time and with the cheapness that they were built. Not only were coolies picked up all along the coast, but they came in immense ship-loads from Canton, being hurried into Portland in anticipation of a prohibition by Congress of their further coming.

Most of these coolies were spoken for before their arrival, and were at once sent to the front of the advancing railways far in the interior. They had scarcely time to recover from their seasickness before their bewildered hands were grasping the strange shovel and were flinging gravel, without any idea what it all meant.

They were not hired, man by man, by their real employers, but through agents of their own race, generally prosperous merchants in the seaports. These merchants would agree to furnish a railway-builder with say five hundred men, at so much a day for a certain number of months. The men were paid by the agent the whole wages offered, about twenty-six dollars a month, in I882, about one-half the wages white men of the same grade were getting. This agent made his profit in the transaction wholly out of the supplies his clients were compelled to buy of him alone.

This system divided the coolies into gangs of forty, to each of which were attached two cooks and one English-speaking 
Chinese as spokesman and leader. By this arrangement the coolie completely lost his individuality, and formed one of so many units to be furnished by a merchant, so many members in a gang to be kept track of by the timekeeper. He was a nonentity, and the most isolated and friendless being in the world.

But though declined as associates, and held in a contempt too good-natured to be scornful, the Chinese were not at that time ill-treated by the Irishmen and other white laborers with

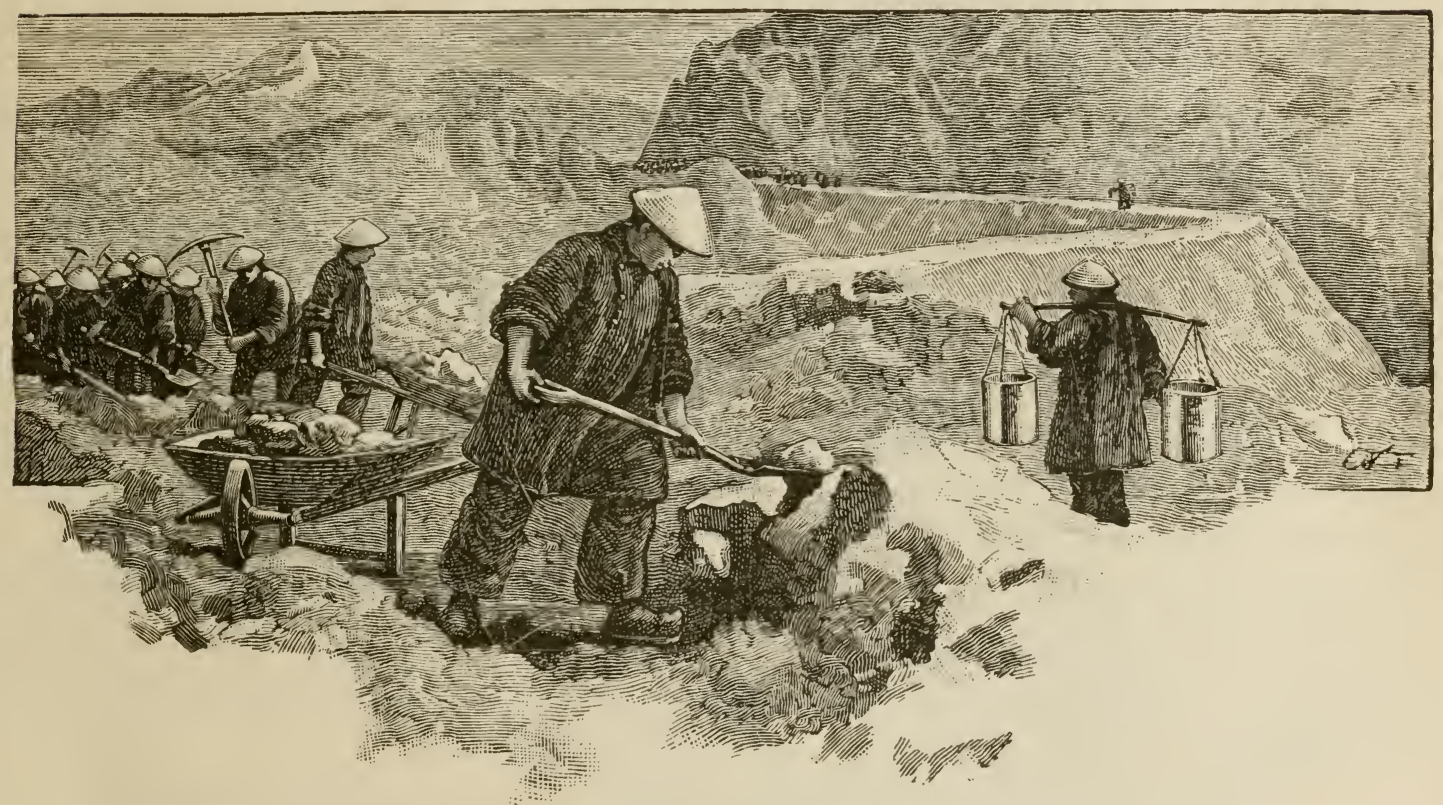

The Strange Shovel.

whom they worked. There were no demagogues in the camps to stir up feuds, and the managers, who were not accustomed to handling affairs with gloves, took care that there should not be meddlers in their way. If a man didn't choose to mind his own business there, he was compelled to do it.

Every man starting inland slung over his shoulders, from the ends of a long stick, in baskets of split bamboo or bundles of grass matting, all of the personal baggage he could get 
through the custom-house, and took it into the woods with him.

On arriving at the scene of work, the coolies would set up the small tents given them by the railway people, or make themselves ingenious "hoodoos" out of ties, brush, bales of hay, or anything that came handy. These might be picturesque in their setting, but sometimes, in a desolate region, they only added to the natural ugliness of their surroundings.

John Chinaman's camp-bed consisted of a board or heap of boughs and the rush-mat in which his blankets had been rolled, together with a more or less ornamental section of bamboo for a pillow, which was also utilized as a box for small valuables. The cook built a half-shed, half-tent sort of kitchen, where he constructed two or three furnace-like stoves out of stones and mud by walling in a square hole in the earthen floor, and contrived a stovepipe out of castaway tin cans.

John's breakfast is early and simple: dried fish, rice and tea as a rule. He has an hour at noon for luncheon (rice), and between meals consumes great draughts of weak, cold tea, carried about, two cans at a time, on a pole balanced across the shoulders, by youngsters not strong enough to do heavy work; for a great many of the later immigrants were merely boys.

Along with his favorite rice and tea John brings from the old country a custom of personal cleanliness which white navvies can never be brought to emulate. Each coolie has his little wooden foot-tub, and his first move at the end of his day's work is to get it full of the hot water which it is the cook's duty to have ready, and then to take a complete bath.

Then follows supper, all sitting about on the ground and chattering like schoolgirls to the rattle of chop-sticks and the banging of tin cups. After supper appear the queer little pipes for tobacco; or perhaps a surreptitious whiff of much-adulterated opium will be indulged in. Many may 
then be seen reading or ciphering or playing native games with their queer little cards.

The Northern Pacific in Idaho and Montana had some six thousand of these Orientals in service during all of r882, besides many hundreds of white people and a few Indians. Other Pacific coast roads employed similar numbers, the total reaching about thirty thousand; and it became a matter of

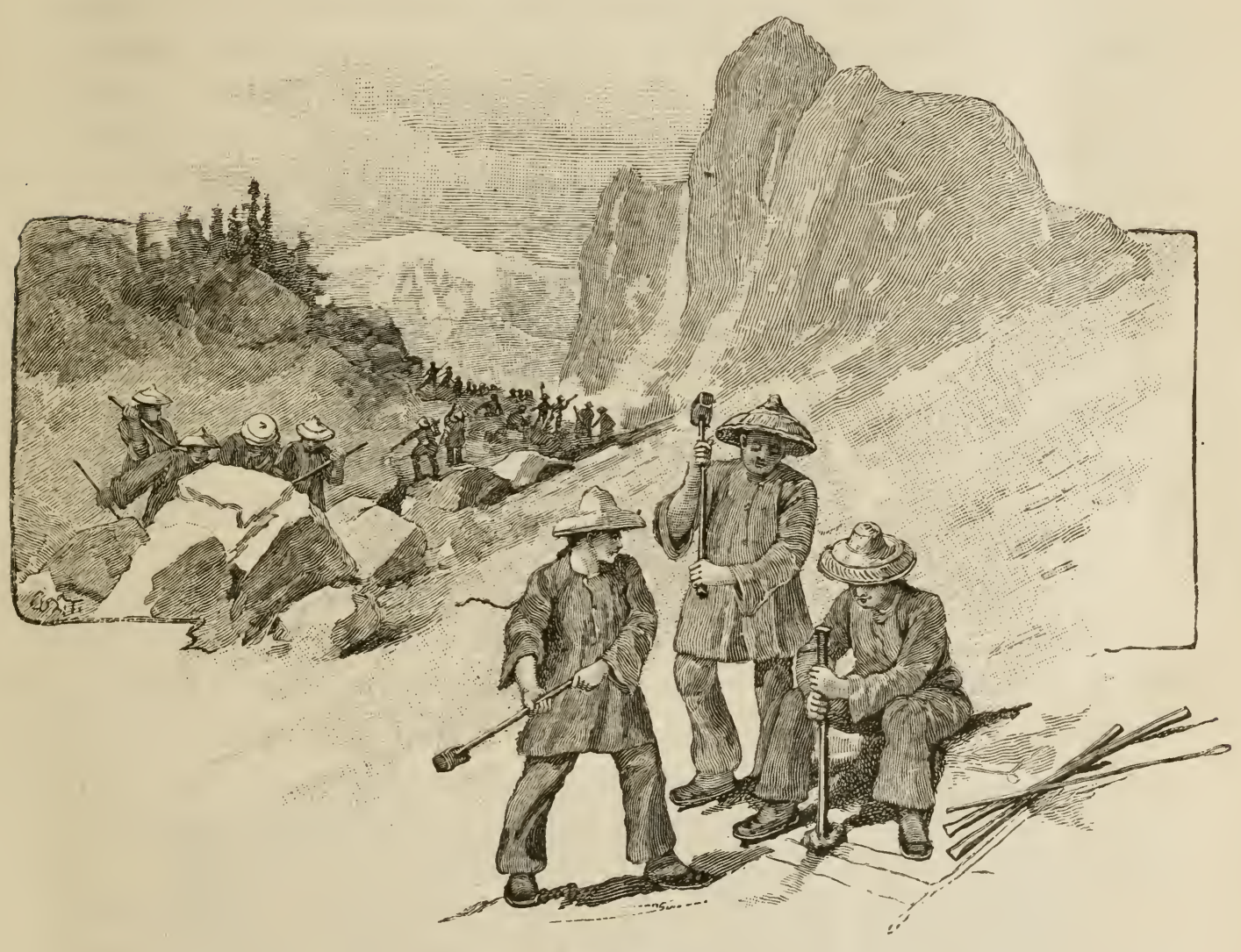

New Work.

anxiety to the leading Chinese in San Francisco and Portland as to how this influx should be provided for when the railways were completed.

Certain kinds of work considered not fit for a white man, chiefly because they required patience, were relegated wholly 
to the meek foreigners; but in general their work was shovelling and rock excavation, always under white bosses, toward whom they sometimes exhibited great animosity, often with good reason.

White bosses were necessary on account of the dishonesty of the Chinese in reporting hours of labor; but they would bribe so unblushingly and successfully that a special set of independent watchmen, called time-takers, was necessary.

In many cases the foremen were inexperienced, so that the older coolies knew better than they how things should be done, particularly in regard to blasting. Hence gangs frequently struck, under conviction that their foreman's directions were wrong and dangerous. Through this, or some other cause, the inferior bosses had a hard time, and were in constant danger of open attack or secret harm.

Not being able to speak the language and constantly irritated, they frequently clubbed the workmen, and on one or two occasions even killed men in the way of discipline. Yet it was not often that the Chinese, born with slavish instincts and accustomed to oppression, turned in revolt or self-defence.

The Chinese proved themselves very skilful in the management of explosives, which were employed extensively all the way through the mountains, and they had great respect for expertness in this direction. I knew of one case where a gang, one of whose number had been killed by its boss, petitioned for his retention because "he heap sabe (know) powder - no kill whole gang o' Chinamans! "'

Though they were not able to get through as much work in a day as white men, they were very valuable to the railway contractor, not only because of their docility and handiness, but because they could be relied upon to stay at work. Very few of them knew of any alternative, and were never restlessly inclined to quit and go somewhere else, which is the ruling disposition in the white workmen of that region. Moreover, they were not inclined to break away on sprees, and 
thus incapacitate themselves for labor for several days at a time.

Near the growing end of every new railroad was an itinerant town of liquor-sellers and all sorts of bad characters, which continually bred delay, waste and riot among the laborers. To these places the Chinese gave no patronage. They had their own vices, the worst of which was gambling among themselves. This was doubtless bad for them, but it did no harm to the general progress of the work. This disposition was a great comfort to the managers, and in fact, was the salvation of the work.

Upon the completion of the railways in 1883 and 1884 , great numbers of Chinese, both old settlers and raw emigrants, made their way to the large towns, whereupon alarmists cried out lustily at the frightful evils to follow; but they were absorbed or went back to China, and the evils have not occurred. A good many were retained as section-men along all the lines, and since that time thousands of Chinese have annually found employment in new railway construction and in coal-mining.

ERNEST INGERSOLI.

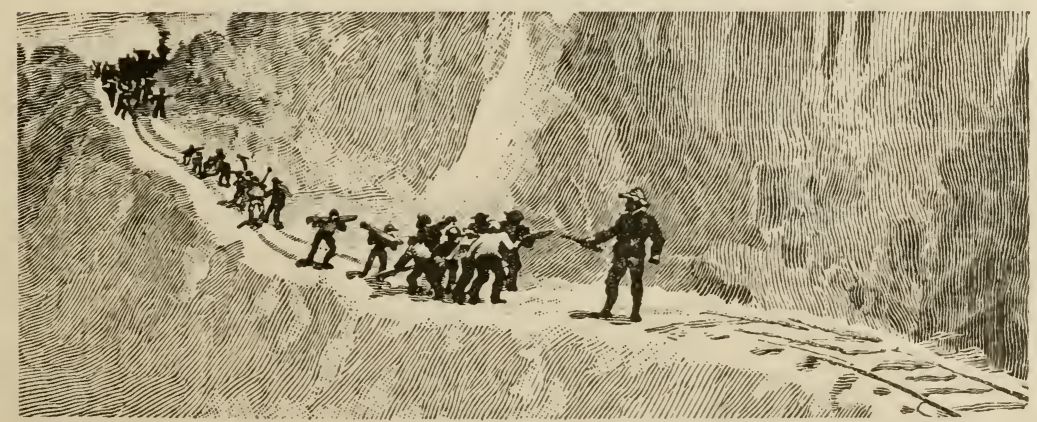




\section{Some Rocky Mountain Animals.}

There is a peculiar charm and interest in Colorado mountains when, after climbing a high peak, we emerge from the forest. The desolate vanguard of skeleton trees, with bleached limbs, which have perished in the forefront of the battle with the elements, gives place to a soft turf that completely clothes the upper part of the mountains from timber-line to summit.

This turf is covered with dwarf Alpine flowers of exquisite beauty. Here are soft cushions of tiny azure-blue stars, there tufts of blue gentian; and by the side of a rivulet whose icy waters cut the rich moss rise the bright, majestic flowers of Parry's primrose and the mauve bells of the Jacob's-ladder.

To botanist, zoölogist and naturalist this ethereal zone between timber-line and peak has peculiar interest, for here he will find Arctic flowers, birds, insects and animals without risking his life on an Arctic expedition. For climate, rather than distance, makes these changes in natural life. Hence our eagerness as we step forward.

What shall we find? What birds, butterflies, plants and quadrupeds live in this region all to themselves, so far above the rest of earth and its inhabitants? We were not long left in doubt, for our appearance was the signal for a series of shrill whistles, which were answered by a chorus of sharp little barks coming from numerous unknown places among the rocks.

After a careful reconnaissance, we caught sight of a yellowish-brown animal like a woodchuck, with long, brown, bushy tail. It lay flat upon a slab of rock like a squatting lizard, repeating at intervals the sentinel whistles we had heard, which were echoed by a chorus of teasing little barks, cheep! cheep! from many invisible throats.

By closely watching the spot from which the sounds 
appeared to come, we were rewarded by seeing a little animal very like a young rabbit mount a rock, stand erect on his haunches and pipe out his sentinel note, which was immediately answered by the cries of others, whom we now saw peeping out from under the stones.

The shrill whistler is the Rocky Mountain marmot, and is very like that cousin of his in the Eastern States which is

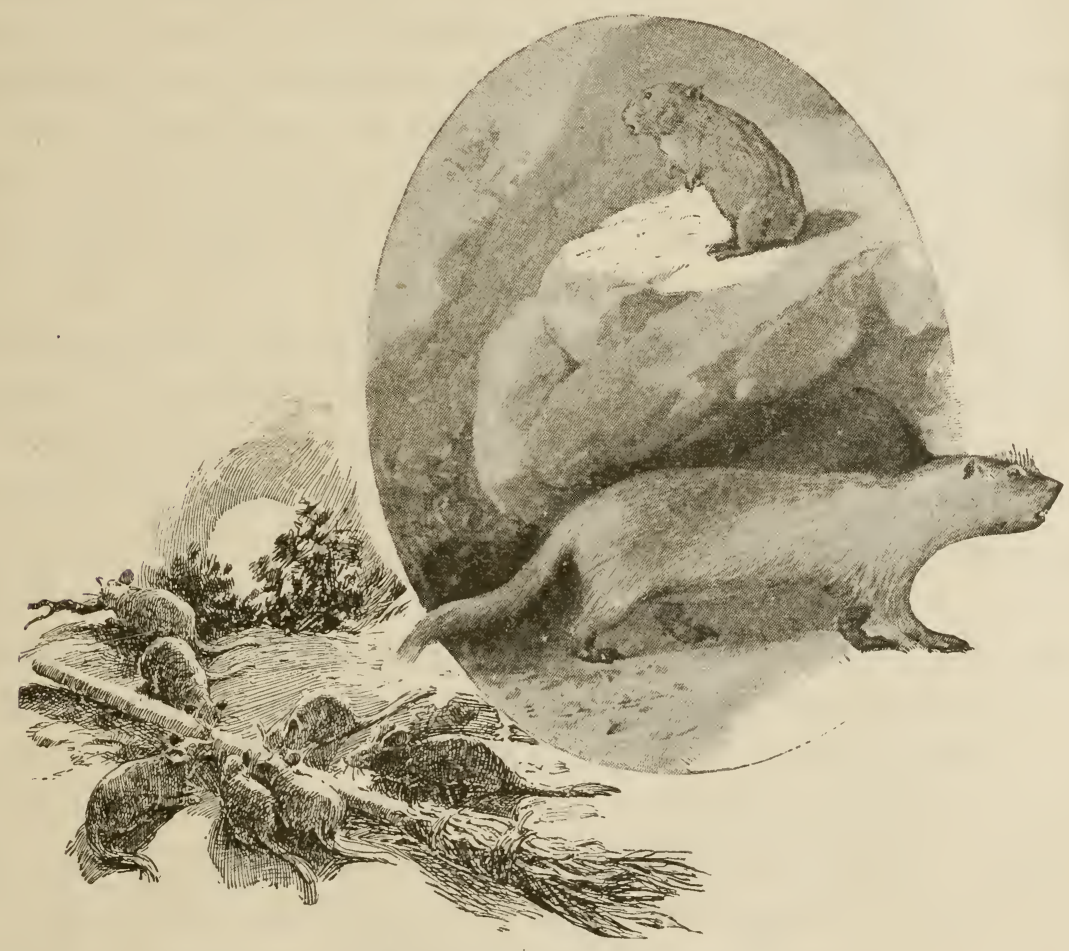

Rocky Mountain Animals.

known as the woodchuck, but is larger, yellower and with longer tail. He lives under the rocks in holes, and is often seen basking in the sunshine on the top of a flat rock or alertly keeping sentinel watch. He lives on the succulent herbage, and lays in a store for winter.

The other little animal that resembles a very young rabbit is not so well known. Naturalists call him the pika, and hunters have named him the coney. As a matter of fact, 
he is identical with or closely related to the conies mentioned in the Bible, and is found on the tops of the mountains of Syria, as well as on the Himalayas. His resemblance to a young rabbit is close, only he has no tail, and his ears are not so large. There is also a difference in his rodent teeth.

The conies live in colonies among the loose rocks, and always have sentinels posted while they are out feeding. The shadow of a hawk or the bark of the sentinel sends them speedily to their hiding-places, from which, almost with equal speed, they emerge to see who the intruder is, and keep up a perpetual barking. They are rodents, and feed, like the marmots, on the roots and stunted herbage, laying up a store of grasses, like little hayricks, against the long winter, when they may be snowed under ten feet deep.

As we walked down among the chaos of loose rock left by an ancient glacier in its melting and retreat, a flock of birds about the size of partridges rose with a whir that startled us, and alighting again a few yards off, suddenly became invisible.

These were the Rocky Mountain ptarmigan; and their invisibility is due to the close resemblance of their plumage to the stones on which they stand. Either because their foes and visitors are very few, or because they trust to their colors for concealment, they are very tame.

These birds change their plumage according to the season of the year. In summer they are gray like the granite, and in winter, snow-white. Their nests are composed of leaves, grass and feathers, lying on the ground. They feed on leaves and seeds of mountain plants.

At the extreme top of the mountain, fourteen thousand feet above the sea, the only living creature we could find was a very active spider, living under the stones and apparently doing well. Under the same stones, too, were the dead, frozen bodies of hundreds of thousands of locusts, which had doubtless been beaten down by a storm on to the peak, and had perished from cold. 
Butterflies, especially little blue and brown ones, were plentiful. In one of singular delicacy and beauty, with large, transparent white wings on which were purple spots, I recognized an old friend which I had first met in the Alps of Switzerland, the Parnassus or A pollo butterfly.

A little gray-crowned finch, with purplish wings, is another frequenter of the peak. It is often seen in flocks about the miner's cabin, picking up a precarious livelihood. When a big storm is coming on, these birds betake themselves to the valley and prairie, and so warn people of its approach.

An eagle may occasionally soar over the peak and alight, and a bear may find the mountain-top a convenient short cut to some place he is bound for on his

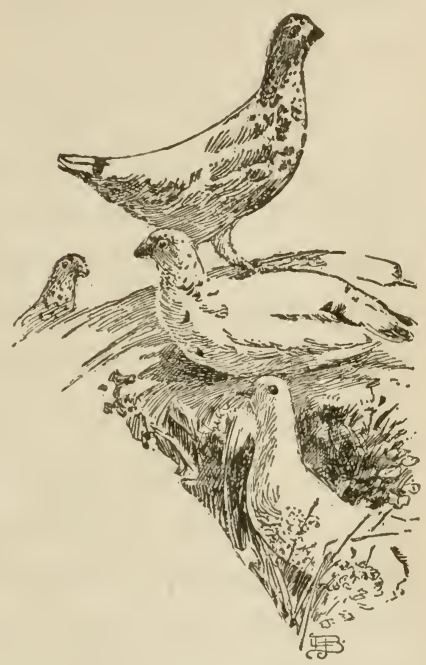

Ptarmigan. travels. But neither of these animals is, like the rest, a true denizen of the mountain-top, both in summer and in winter.

One of the most singular creatures in this region is the Rocky Mountain rat. Not that anything is very peculiar in his appearance, since he differs but. little from a rather large ordinary rat, except that his ears are larger, while his fur is soft and brown, like that of the chinchilla, and his tail more bushy. But "for ways that are dark and tricks that are vain" the mountain rat is decidedly " peculiar."

When wandering among the rocks and canons, you may often observe, in crevices high up the cliff, an accumulation of sticks and rubbish, which you might suppose to be the nest of an eagle, or even the couch of a Rocky Mountain bear, for which it is frequently large enough. But it is neither of these.

It is the nest and home of a rat, or a colony of rats, which, like a few other animals, have an extraordinary mania for general accumulation, and in particular for collecting certain things of a bright and shining appearance, seemingly of no 
possible use to them. They are instigated by a veritable spirit of thieving.

Nothing seems to come amiss to them, from watches, tin plates and silver spoons, down to the bones and horns of wild animals, and even pieces of stone and slate.

These precious trophies are dragged with infinite pains up to the monstrous nest in the clefts of the rock, which is composed of twigs, rubbish, and the flotsam, jetsam and bric-à-brac of mountain, forest, stream and valley. As a naturalist, I have found a mountain rat's nest as instructive about the natural history of a neighborhood as a local museum in a small town.

The rats do not confine their stealing to their natural surroundings among the rocks. They are much given to taking up their abode in the lofts and roofs of log cabins. In the night they are heard from, by certain mysterious ghostly rappings and tappings, and in the morning, perhaps, by the absence of some bright article from the breakfast table, laid overnight. When anything of this kind is missing from certain cabins, the first place to be searched is the mountain rat's nest.

The rats' industry. is as remarkable as their thieving. They spare no pains to convey away their booty, and the size and weight of things they carry off, and even drag up a steep hillside, are astonishing. In many cases the robbery must involve the labor of a whole confederate band. When we were engaged in geological explorations in Wyoming we had an example of this.

We were digging out, at the time, the fossilized remains of a gigantic lizard, and were in the habit of leaving our tools geological hammers, butcher-knives, brooms, etc.-in the quarry or on the dump, when we went home to camp for the night. One morning, returning as usual to our work, we found that everything was gone, with the single exceptions of a heavy spade and pickaxe.

Our first impression was that the quarry had been raided 
by tramps, but on looking around a little we espied our long-handled broom lying on the side of a steep hill, some fifty yards away. Not far from it were the geological hammers. The marks of sharp little teeth on the handles showed who the thieves were.

By following in the direction in which the articles had been travelling, we came on a large mountain rats' nest, sheltered in a wide crevice in a sandstone ledge. We revenged ourselves on the little marauders by drawing daily from their nest materials to build our noonday fire. Yet after many such reprisals, the nest still held out.

I took a rough inventory of some of the materials composing it. It consisted mainly of sticks, leaves and twigs, and mingled with them were the bones of various wild animals, the skull of a coyote, the feathers of an eagle, spores of prickly pear, thorny branches of prickly greasewood, and here and there, on the outside, pieces of slate, as if laid on for a finishing touch.

In the heart of this rough mass were the cozy sleeping apartments of the rats, made of soft moss. The motive of all this accumulation seemed to me to provide warmth and protection against the intrusion of other wild animals.

A mountain rat finds a large crevice. He makes up his mind that this, no matter how big, must be filled, to keep out wind, snow and other animals, and for this purpose he makes use of any sort of material that comes to hand.

As regards his choice of shining and gay materials, it may be that he has an eye for decoration and the beautiful, like the bower-bird of the tropics.

Prof. Arthur LAKES. 


\section{Where Railroads Go.}

The railroads of the Rocky Mountains present some of the most wonderful examples of skilful engineering in the world, and they carry passengers past scenery unsurpassed anywhere in grandeur.

Even those who have gone through the Grand Cañon of the Arkansas in Colorado, on the Denver \& Rio Grande Railroad, and have been atved by its silent and gloomy splendor, may not know that before the railroad was built the narrow river filled the space between the rocky walls so that neither man nor beast could enter. There was not even a footpath by the river's brink, and no boat could navigate its shallow but turbulent waters.

The construction of the Denver \& Rio Grande Railroad was begun in 1870 . It was a mighty undertaking. Entering the canon from the little town of Canon City, at its mouth, one is almost immediately shut in by two nearly perpendicular walls, rising now and then more than two thousand feet.

The road-bed in some places is cut out of the solid rock; in others it lies on rocky grades made in the river-bed. At times the laborers were lowered by ropes from the high walls above to drill and quarry and blast out a line for the road, and in the entire cañon, which is about eight miles in length, hardly forty feet of the track lie in a straight line.

The road winds around sharp curves under great overhanging rocks; it crosses and re-crosses the noisy little stream, made narrower and noisier by the road-bed which has encroached on a right of way that was never before disputed.

Out and in the train goes among the deep shadows and the tumbled rock piles, grim and red, of the Royal Gorge, a part of the canon about two miles long, where the culmination of rugged mountain grandeur and magnificence is reached. One wonders if there are any limitations to the achievements 
of modern railroad engineering when trains go easily and speedily through places once inaccessible to man or beast.

Another line of mountain railroad of great interest is the La Veta Pass line, that runs over the Sangre de Christo mountain

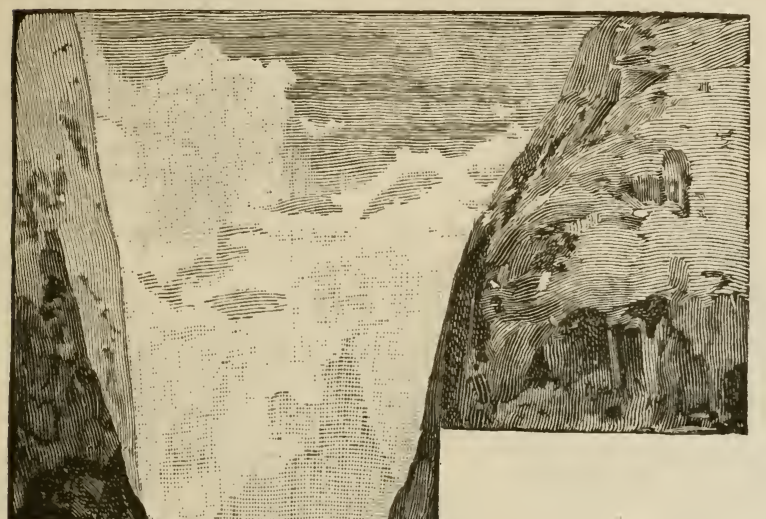
range. Here an elevation of nearly twentyfour hundred feet is reached in thirteen miles, and at one point the grade is more than two hundred feet to the mile for a distance of three miles.

Before the pass is reached the Spanish Peaks are seen rising above the other mountain summits to heights of twelve and thirteen thousand feet. They stand apart from the other summits, rugged and majestic.

The Denver \& South Park line of railroad, reaching to the Gunnison country, passes through a tunnel seventeen hundred feet long, at the great height of eleven thousand feet. What a victory over natural obstacles this means can only be understood by those who have gone over this line of road. Passengers glancing out of the car windows hold their breath in places where the train seems clinging to the mountain wall, thousands of feet above the dark and gloomy canons below. One cannot help thinking of the frightful result if a wheel should leave the track, or one of the overhanging rocks should come crashing down.

One may ride many miles on these wonderful railroads without seeing a house, and the stations are often many miles 
apart. The towns and cities, when reached, often consist of a single house.

I remember one such city, away up on the summit of a mountain ten thousand feet high. The engine behind which I rode went panting and puffing up to it one bright day in June several years ago. The last mile of the ascent was a noble pull up the steep and flinty side of the mountain.

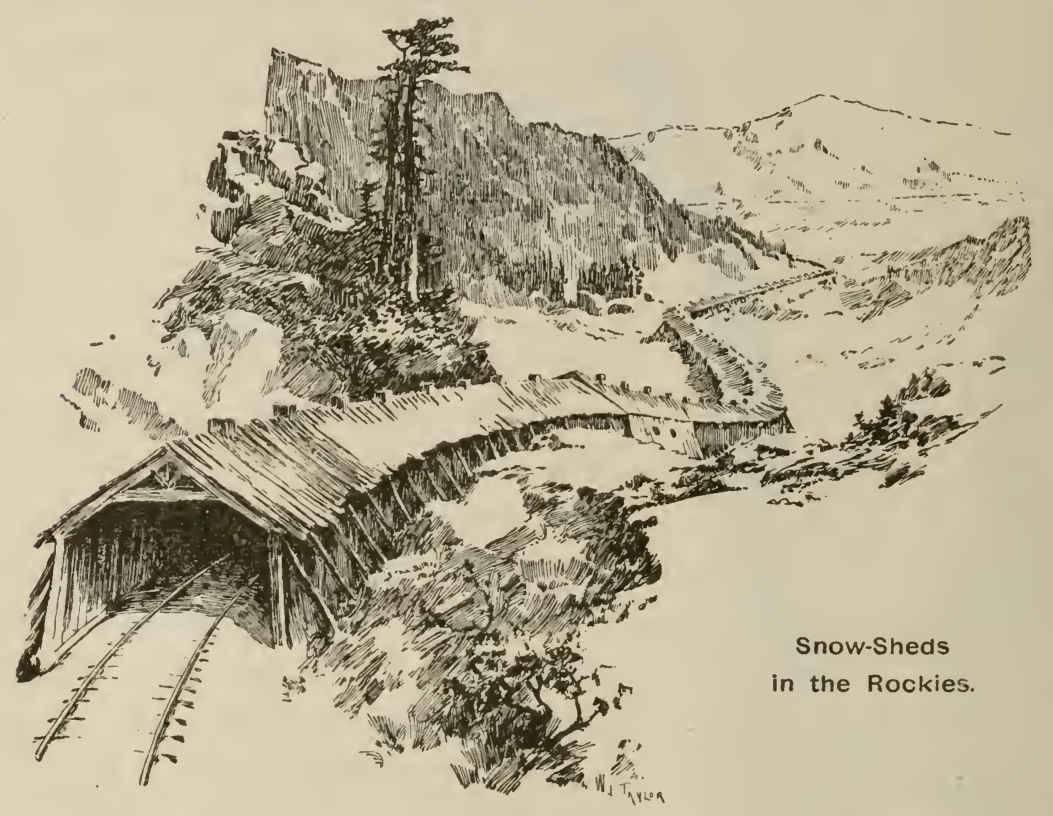

Whirling suddenly around a curve, the ascent became less abrupt, and we stopped before a tiny station, painted bright blue, standing on a bit of level ground a few feet square. There were bright red calico curtains with white lace borders at the windows, in which were plants in bloom. Through the open door one caught a glimpse of a tidy little room, with a bright rag carpet on the floor, and with walls covered with gay picture-cards.

A tidy little woman, with the whitest of aprons and the starchiest of calico dresses, came to the door, on the step 
of which a splendid old Maltese cat lay asleep in the sunshine. A canary sang shrilly within, and just before we went on our way a curly-headed baby came creeping across the floor and was caught up in its mother's arms to wave

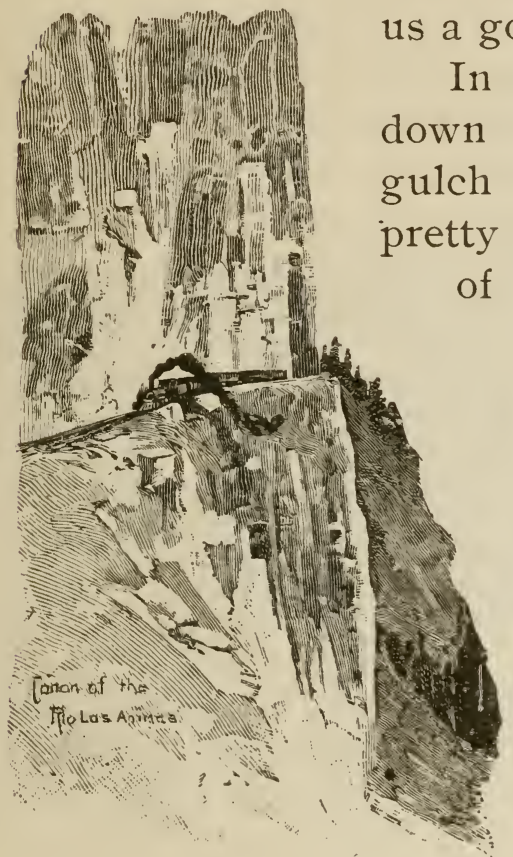

In another moment we were rushing down the mountain-side to the gloomy gulch below, leaving far behind us that pretty picture of home life in the sunshine of the heights. Perhaps railroads go to more remarkable places in Colorado than in any other State in the Union; but in California there are railroad wonders scarcely less noteworthy.

The passenger who, for the first time, climbs the Tehachapi Summit Pass on the Southern Pacific Railroad is astonished, after he has left behind him the level lands of the San Joaquin valley, and is scaling veritable mountain heights, to find the train crossing another railroad track, though at a height considerably above it. "Can it be possible," the passenger asks, "that there is another railroad running along the top of this lonesome mountain in the wilderness?"

Then he is told by some fellow-passenger, probably with a smile, that he is crossing the track that he himself has just ridden over. The road has made a loop upon itself; and while the train, in making the circuit of this loop, has not progressed at all toward its destination, it has risen a good many feet higher toward the summit which it must climb before it starts on its descent.

J. L. HARBOUR. 


\section{Digging Up a Fossil Monster.}

The Rocky Mountain region is a treasure-house of curiosities, of minerals, crystals and fossils. Fossil shells, fossil leaves, fossil reptiles and mammals abound.

The great upheaval of the Rockies has brought these wonders to light from their sepulchres deep in the earth. The upheaval of the granite core has tilted up and exposed the deeply buried strata along its flanks in such a manner that any one can study a thickness of a mile or so of them in an afternoon's walk by passing along their upturned edges. Thus he can see, as it were, a mile or more into the material composing the bowels of the earth without accompanying Jules Verne on an imaginary trip to the centre, or boring a well a mile or more deep.

I was spending an evening at a country resort in a picturesque locality among the upturned rocks of the foothills. At the request of the guests of the hotel, I gave them a brief lecture or sketch of geology, and whilst describing the succession of periods and rocks composing the earth's crust, and the succession also of the different animals that had lived on those rocks, I happened to say that the rocks on which the hotel was built belonged to those of the Reptilian period, and that possibly strange reptiles might be sleeping in their tombs beneath its foundations.

The next day the guests, fired with an interest in geology, proposed an excursion among the rocks. After we had climbed over ridge after ridge of red sandstone, limestone and marls of the Triassic period, we reached the foot of a very prominent hogback, or ridge, composed of variegated marls, clays and sandstones, when one of the party in advance called out that he had found the impression of a fossil tree-trunk on a fallen slab of sandstone. As such a fossil is not uncommon in this region, I was not surprised. 
On reaching the spot I saw that the impression on the slab was far too smooth to have been made by the rough bark of a fossilized tree. It was more like the impression a stovepipe

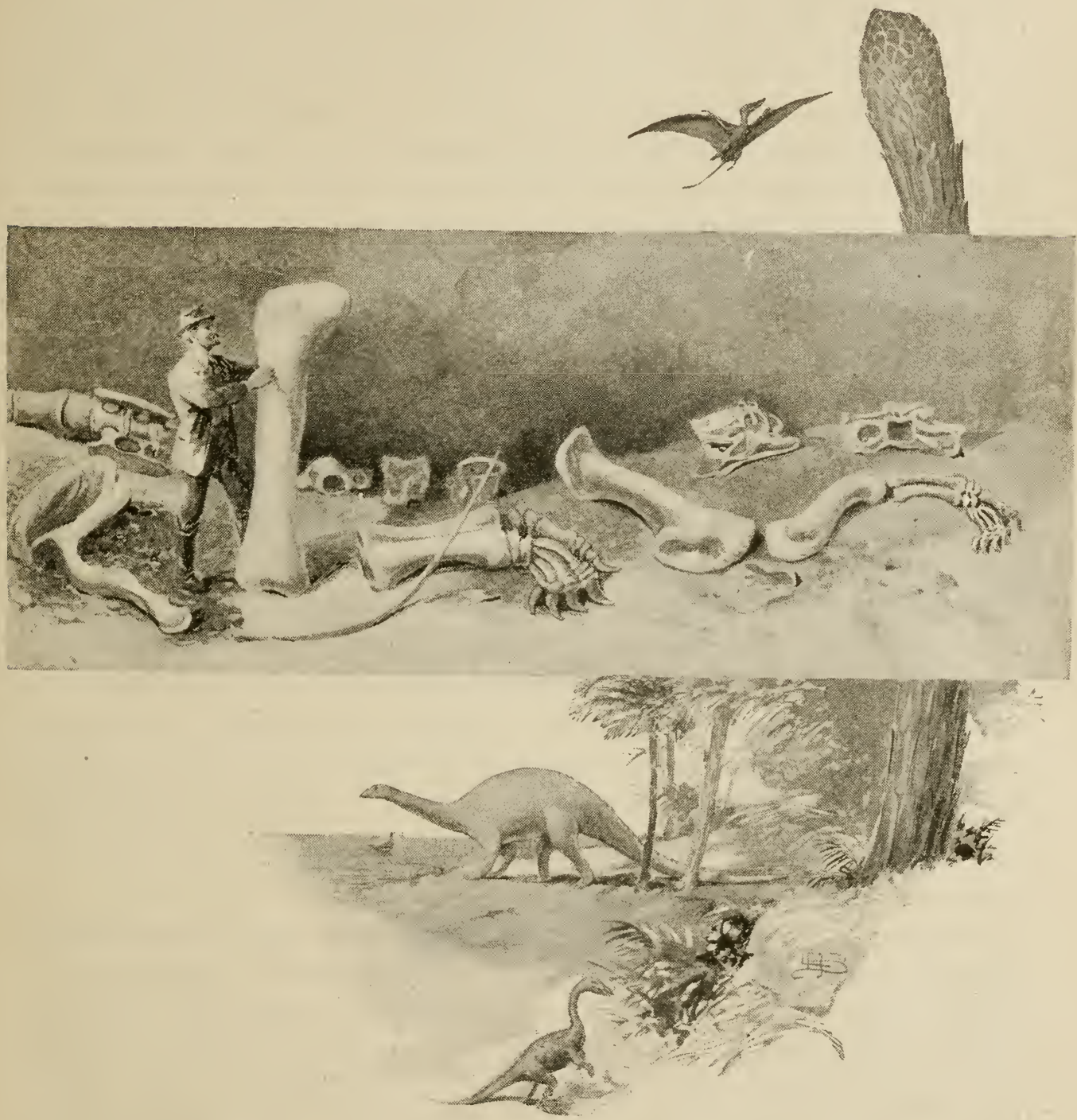

The Atlantosaurus, as found and in life.

would have made on a soft bed of clay. In one corner were little porous, pinked fragments adhering to the rock, which I recognized as fossil bone. 
"This," I said, "is no tree, but the impression of the bone of some prodigious monster."

Forthwith we clambered up the cliff to the spot whence the slab of rock had evidently fallen from its parent ledge; and there at our feet lay three huge vertebræ, partially imbedded in stone, each about a foot in diameter, and all united to form the massive sacrum of the monster, to which the tail is attached. Hunting among the bushes below the ledge, we found the broken ends of limb bones, like Hercules warclubs, while other fragments could be seen still imbedded in the sandstone of the ledge.

We sent to the village and procured a quarryman, tools and blasting powder, and began opening up the rocks with wedges and powder. This resulted in the discovery of many other bones and some spoon-shaped teeth.

We watched for the results of the blasts with great interest. Once when the smoke had cleared off, and an overlying slab had been blown to pieces, there lay beneath it a perfect limb bone, black as ebony, and five feet in length.

At another time the perfect skull of a crocodile, with teeth complete in the sockets, was uncovered. It was doubtless the skull of a creature which lived in the same swamp with the larger animal. Bones and shells of turtles and fish-bones were found with the remains, showing that the animal, whatever it was, must have lived and died in the vicinity of lakes, or rivers, or fresh-water swamps.

Large vertebræ were quite common, especially those belonging to the neck and tail. These, which looked like buffets when lying on the dump, varied in size from fifteen inches in diameter down to three or four inches. Some belonged to the neck and back, and others to the tail. Sharp, black, scimitar-like teeth, belonging to some carnivorous species, were occasionally found, mingled with the other remains.

The largest bone found was a gigantic femur, or thighbone, which, from the enormous proportions of the butt ends, 
was as first estimated to be nine feet in length, making allowance for a portion of it missing ; but it turns out to have been only six feet four inches.

Curious to know the nature of this prodigious creature, we sent off a car-load of bones to Professor Marsh of Yale College, a great authority on fossil animals. He informed us that the bones were those of a gigantic land-lizard, or Dinosaur, and he declared, from the size of the bones, that it was far greater than any that had hitherto been discovered. He named it forthwith the Atlantosaurus immanis, or the huge Atlas lizard, as a compliment to Atlas, who is supposed to have carried the world on his shoulders.

This is the greatest land animal that has. ever been discovered, and in all probability the greatest that ever walked this earth. The only bones at all comparable to it are those of the whale.

The length of the animal is computed at between sixty and eighty feet, or possibly even more. Its height, as it strode along on its four stout legs, was between twenty and twenty-five feet.

As the bones of the creature were not all found, or complete, the length might be estimated by the size and number of the vertebræ as compared with those of the modern crocodile. As for height, perfect legs were found whose length was upward of fifteen feet. Allowing five feet or a little more for the space between the top of the limb and the ridge of the back, twenty feet is a very moderate estimate.

It would be difficult to compare it to any living animal. It was a gigantic lizard, mounted on tall, stout, elephantine legs, with a long, thick, powerful tail, and a longish, thick neck, tapering to a small, almost serpent-like head, far smaller than one would expect for so huge a monster. The skin may have been covered with shining scales.

The atlantosaurus appears to have been quiet and harmless in habit, and dependent mainly upon his vast size for protection against other more formidable kinds. The character 
of the teeth imply that he was herbivorous, and his habits may have been somewhat like those of the hippopotamus.

As a land animal, he walked proudly among the forests of the Jurassic period, or baked and wallowed in the marshes that then surrounded the young, low-lying Rocky Mountain region, and stretched down to the sea, where sea-serpents

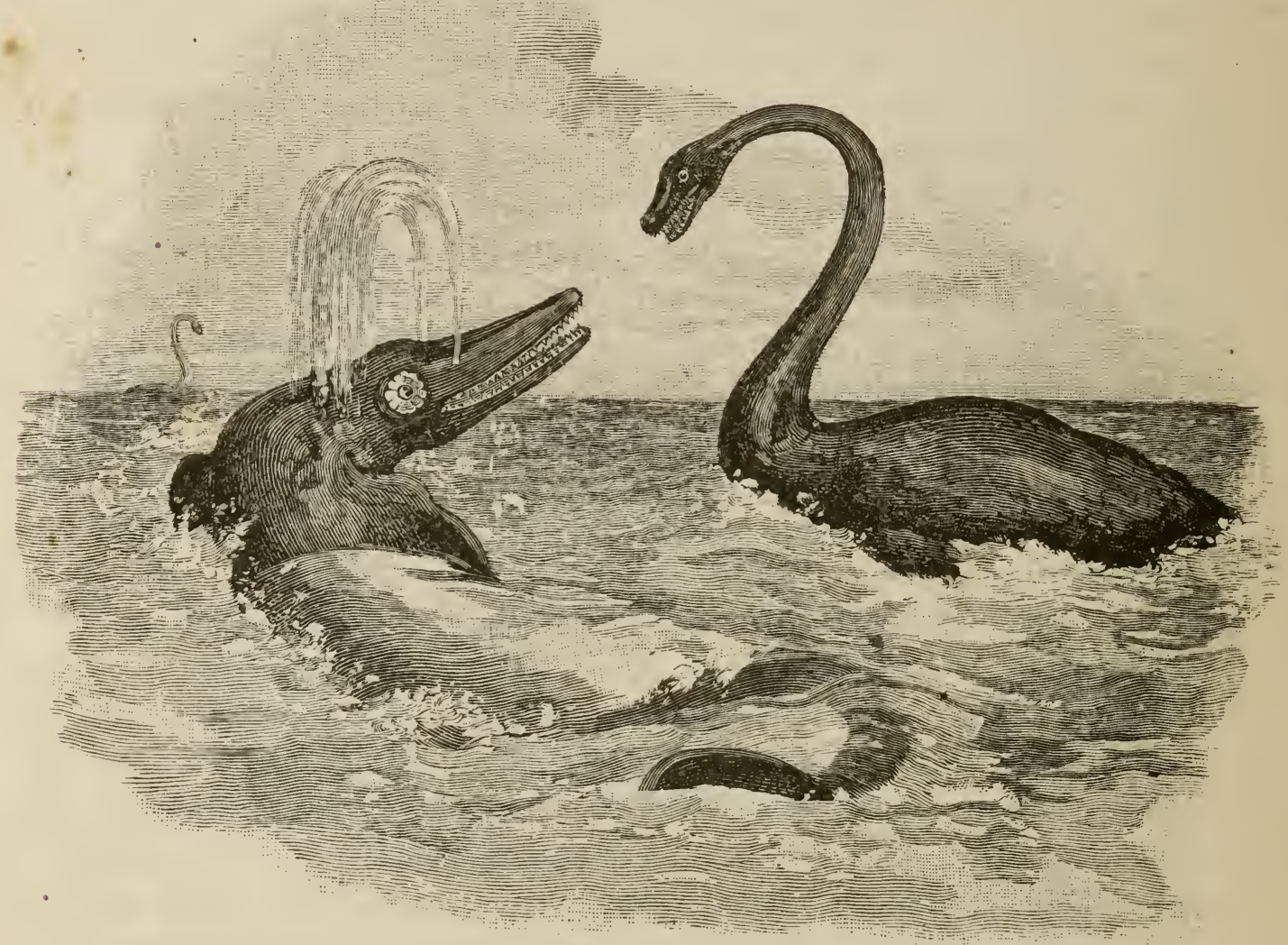

Ichthyosaur and Dinosaur.

and many strange reptiles held sway in the waters, while reptilian-like bats and birds flew in the air.

On land there were many species of these dinosaurs, some of which we discovered later in Wyoming. Some were herbivorous and some carnivorous; some walked upon all fours, others hopped along on their long hind legs like kangaroos, and others were very bird-like in appearance 
and gait. They were of all sizes, from that of the great atlantosauri down to lizards no larger than a cat.

With these remains we found in Wyoming those of tiny mammals, probably the first known, resembling kangaroo rats.

The question is sometimes asked, "How long ago did these monsters live?" To this we can give no definite answer, further than that it was very long ago - thousands, perhaps millions, of years ago. Some idea of their great age may be obtained by considering the thickness of rocks that lie above them.

These rocks were slowly and gradually laid down, as sea, river and lake are slowly laying down their beds of mud and sand to-day, to become in time solidified into shale and sandstone. There has lain above the tombs of these animals as much as ten thousand feet of rock, all of which was formed, of course, after they were dead and buried.

Much of this rock is a fine shale or clay, which must have formed very slowly at the bottom of a deep sea. The rest is sandstone, which may have formed a little faster. Some geologists estimate the thickness of rock to have been formed at the rate of from one foot in one thousand to five thousand years. Multiply, then, your ten thousand feet by either of these numerals, and you will see how very long, even at the lowest estimate, it must have been since these bones were first buried in the mud of the ancient Jurassic marsh.

These bones were quickly covered up and sealed from the influence of the atmosphere. In this state they were soaked through and through with water carrying minute particles of quartz and mineral matter, and as the tissues of the bones decayed, they were microscopically replaced by this quartz matter, which in some of the larger bones is a beautiful agate and carnelian.

Prof. Arthur Lakes. 


\section{A Petrified Big Tree.}

In a little meadow-park called Florissant, nine thousand feet above the sea and in the heart of the mountains in the state of Colorado, we came across half a dozen stumps of trees from ten to fifteen feet in diameter, turned into solid, hard stone.

One of the largest of these stumps had been partially excavated from its bed by some enterprising people who had intended to carry it to the World's Fair at Chicago.

It stood about twenty feet above its base, and was fifteen feet in diameter. As it was too huge and heavy to transport bodily, they tried to saw it up into sections; but fortunately for Colorado, its flinty hardness was more than a match for thin stone-saws of soft iron, which are still sticking in the tree as monuments of their discomfiture.

So wonderfully has the stony material replaced the texture and grain of the original tree, and even in some parts simulated its color, that but for its unusual size any one might have passed it by as an old dead pine stump felled by some early settler.

It was easily recognized as a fossil representative of redwood. Not only is the rough texture of portions of the thick bark preserved, but even the minutest wood-cells and rings of yearly growth are retained. Sometimes a faint tinge of iron-rust nearly restores portions of the wood to its redwood color, but the prevailing tint is an ashen-gray, like that of an old dead stump.

As you pick up one of the chips scattered around by the hammers of tourists, its weight and hardness alone convince you that it is really stone and not an old cedar chip left by the axe of an early wood-chopper. To complete the resemblance to certain parts of the living tree, sap-vessels and veins are here and there filled with what appears to 
be gum, but it is really semi-transparent agate, opal or chalcedony.

When we make fine, thin sections of the fossil wood and put them under the microscope, we find a peculiar pattern of the wood cells which is the same as that of the modern sequoia, showing that these lone trees, over a thousand miles

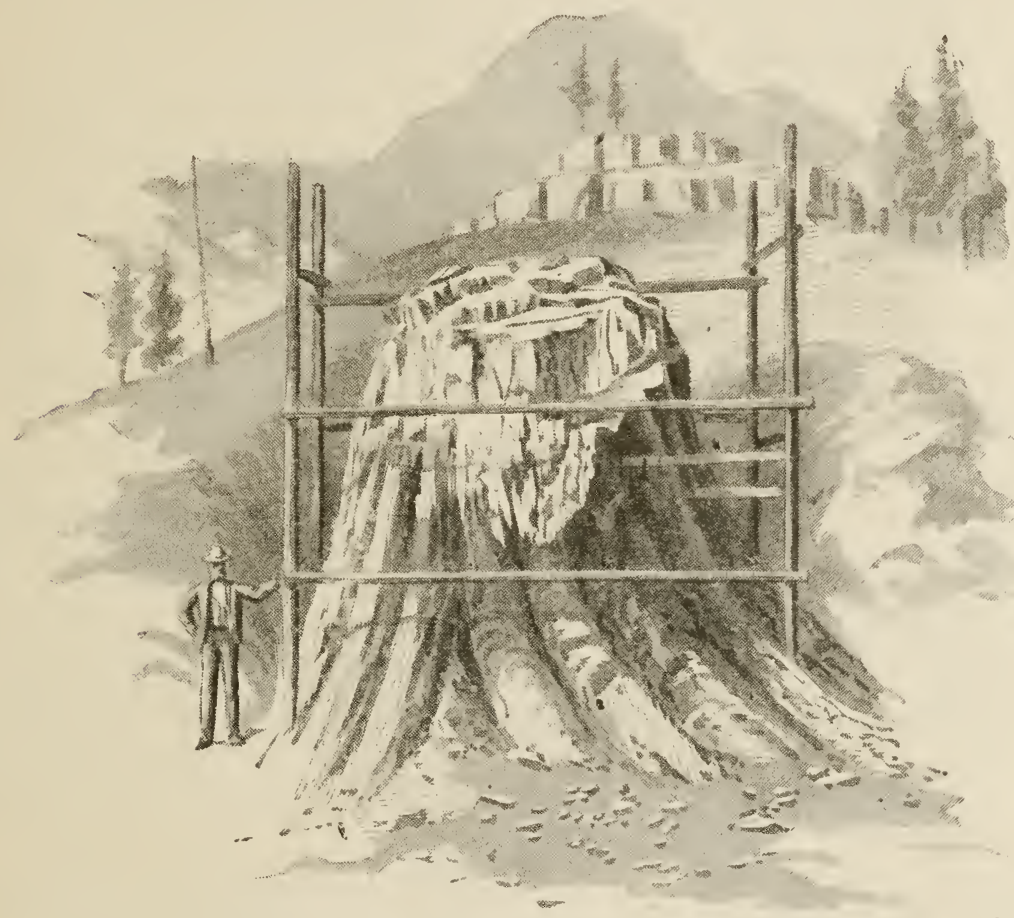

A Petrified Tree-Stump.

from the Pacific coast, are the stony representatives of the great living sequoias.

How was this tree so wonderfully changed into stone, and how comes it here, almost alone in the Rockies? Stone it certainly is ; moreover, there is not a particle of the original tree in it, any more than there is flesh and blood in a marble statue or a plaster cast. It is a stone statue or restoration of a once living tree, far more perfect than that of any statue by the greatest sculptors. 
It is not an uncommon notion that certain substances or bodies have, after life is extinct, some mysterious power in themselves of turning themselves into stone; but such is not the case. A buffalo dies on the prairie; his flesh rots and passes away into various gases; his skeleton lasts a few years longer and then passes into dust and soil. Similarly a tree dies, rots, falls to the ground and makes soil for other trees to grow on. Neither buffalo nor tree has any elements in itself that can transform any part of it into stone.

Suppose, on the other hand, a tree like our sequoia to grow near a marsh or lake. 'The waters of the lake encroach on its roots, kill the tree, and bury its stump in mud while the upper portion, falling into the lake, becomes water-logged, sinks to the bottom and is entombed in mud, which arrests rapid decay. In this condition petrifaction may gradually take place.

Nearly all waters contain mineral matter, such as iron, soda or lime. If the waters are acid and heated, as they are apt to be in the neighborhood of volcanic action, they generally contain quartz or silica in a dissolved state, which they deposit in a gelatinous condition, like gum arabic. This afterward hardens into agate or chalcedony as hard as glass. If clayey matter is added to it it may form some kind of hard stone like jasper.

Suppose a tree, then, in the bed of a lake to be saturated through and through with such mineral-bearing water. The larger pores and veins are quickly filled with agate, opal or chalcedony, so like pine gum. Then a long protracted, minute work goes on. As each tiny particle or wood-cell rots away, it is replaced by a minute particle of quartz or stony matter, till, when at last every living element of the tree has vanished, a microscopically perfect restoration of the tree, both externally and internally, is left behind in stonea monument for all time, of the tree that lived and died ages and ages ago.

All trees that have fallen into lakes and rivers have 
not been so preserved. Peculiar circumstances have been necessary for such petrifaction. The most favorable circumstances are often the presence of acid and hot springs in a volcanic neighborhood, such as we see in the geysers of the Yellowstone, where there are whole forests of petrified trees.

The surroundings of these fossil trees are no less interesting than the trees themselves. The roots are imbedded in shale and sandstone, the solidified mud of a primeval lake. This is composed of grains and fragments of volcanic lava, often as fine as the finest dust.

Opening the thin layers of this petrified mud with our knives, we find numerous impressions of fossil insects, such as ants, dragon-flies and tropical lantern-flies. A fossil butterfly impression has also been found, one of the very few ever discovered ; so perfect that the color-pattern on its wings can be distinctly made out, and the species identified.

Mingled with these are equally perfect impressions of fossil leaves of a semi-tropical character, such as those of a palmetto. A fossil bird and fossil fishes have been found. All the remains indicate the existence at the time of the lake of a semi-tropical climate, very different from that of this neighborhood to-day.

From such remains and other discoveries we can get some idea of the history of the lake and its fossil trees.

Some thousands of years ago a small mountain lake nestled among these hills. Its banks were surrounded by luxuriant semi-tropical vegetation, among which, close to the edge of the lake, towered the great sequoia. Volcanic eruptions took place along the shore of the lake, and by violent explosions filled the air with lava dust and ashes, which fell in showers into the lake and formed its mud.

Leaves of trees that had been blown into the lake, and insects that perished on its muddy flats or in its waters, together with the water-logged stumps of trees, were periodically buried beneath these eruptions of volcanic mud. 
Hot, acid springs accompanying or following the eruptions assisted in the process of petrifaction.

The eruptions in time ceased, the lake dried up or was drained off, glaciers and floods cut ravines in the old lake beds and exposed their fossil treasures.

The sequoias are probably the oldest, as well as the largest trees, now growing on this planet. They are survivals of an age long past. They were, geologists believe, among the earliest genuine forest trees to appear on this planet.

Before that time there were but seaweeds and gigantic ferns, rushes and mosses, till about the middle of the earth's history, at the time when the great lizards appeared. With them came the great sequoia-tree. Around it were strange, gigantic forms of animal and vegetable life; and its survival among us to-day seems almost as strange as it would be to see one of those terrible, gigantic lizards walking among the trees of Central Park and passing from branch to branch.

The sequoia saw the age of great reptiles fade away and give place to that of almost as great and formidable mammals. The sequoia, or rather its descendants, saw man arrive upon the earth, and doubtless witnessed what, if we knew it, would clear up the mystery of the missing link. To-day it sees the railway train fly through what is left of its forests, and has the telegraph wire pinned to its thick bark.

In the present age there are but two varieties of sequoia, and these are confined to the Pacific coast. In geological times there were twenty-six varieties, scattered over the world from the extreme Arctic Circle to Australia. This wide distribution accounts for our finding the fossil stumps in Colorado.

Prof. Arthur Lakes. 


\section{The Holy Cross and Twin Lakes.}

The progress made by railroads during late years has rendered accessible many points of interest and beauty in the Rocky Mountains that could be reached before only by long and wearisome journeys on horseback and in wagons.

One of the most remarkable points in northwestern Colorado is the Mount of the Holy Cross, about which little has been written. This mountain is nearly three miles high, very rugged and barren.

Away up above the great gray rocks, above the lofty pines, amid the barren boulders, the Holy Cross lies outlined, on summer days, beneath the blue sky.

The mountain derives its name from this cross, which is formed by the deep snow lying in two depressions nearly at the summit of the mountain; these depressions, or ravines, are so formed by nature that they cross each other at right angles.

They are very deep, and become filled with snow during the winter months. In the summer the snow melts from around the ravines, and leaves the great white cross distinctly revealed against the gray rocks.

Under the light of a full moon, in which all the splendors of the mountain are enhanced, the Holy Cross lies gleaming in its snowy purity, and awakens in the beholder's heart thoughts of the sacred cross on Mount Calvary upon which our Saviour died. Even the rough class of men found in this newly settled part of Colorado regard the Holy Cross with a kind of awe.

The cross is not visible in the winter, when the whole summit of the mountain lies buried under many feet of snow. It is, indeed, a singular work of nature, and well worth the long ride you must take to either of the points from which the finest views of the cross are to be had. 


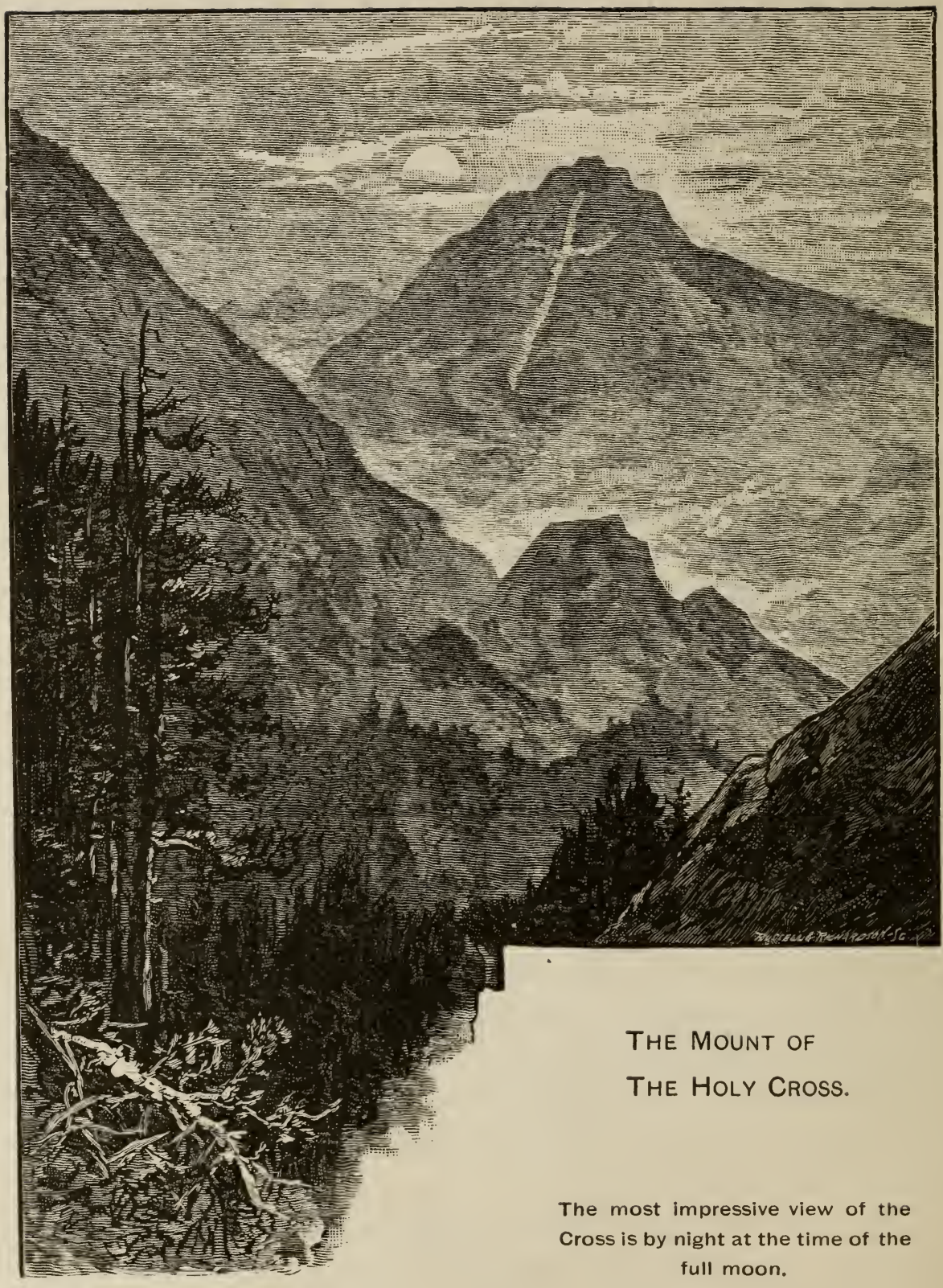


With the present railroad facilities the journey from the Mount of the Holy Cross to the Twin Lakes can be made in a day. You go through the picturesque little mining town of Red Cliff, over Tennessee Pass, and across Tennessee Park to Leadville.

The lakes are fifteen miles southwest of Leadville, and lie in an elevation of over nine thousand feet above the sea-level.

They cover an area of about four miles in length by one and one-fourth miles in width, and are separated by only a narrow strip of land. They are surrounded on three sides by lofty mountain heights that slope down to the very water's edge.

On the other side is the wide valley of the Arkansas, beyond which rises another lofty range of mountain-peaks, clearly defined against the sky, although they are many miles distant. On their summits the snow lies during all the bright summer days.

The lakes contain great numbers of the pretty speckled mountain trout that are so great a luxury in their season.

Fishermen are generally very lucky, although the water is so perfectly clear that the fish in the depths below can see the human monster at the other end of the line.

The speckled beauties can be seen darting here and there far below you as you glide in the gaily-painted little boats over the ever placid water. In some places the water is very deep; it has been sounded to a depth of eight hundred feet, and it is probable that the lakes are not deeper than that in any place.

Boys who take delight in thinking what a good time they would have swimming in these beautiful, tempting lakes, would be very likely to jump out of the clear waters more quickly than they jumped into them, for in this altitude the water is several degrees too cold for bathing, even in the warmest August days.

In summer the air is delightfully clear, bright and cool. Persons accustomed to languish in the terrible heat of the 
East would at the lakes enjoy the novelty of snuggling up under several blankets during the warmest summer nights.

Here is found a sure and safe retreat from Old Sol's fiercest rays. It is one of the highest summer resorts in America, if not in the world.

Since Leadville came into existence the lakes have become a very popular place of resort, and a number of good hotels have been erected.

Tourist and camping-out parties come here during the summer months, and add to the picturesqueness of the surroundings by pitching tents all along the shores, and roughing it in a healthful, if not entirely comfortable, manner.

Students with a fondness for geological investigations could not find a better locality in which to gratify their inclinations. Some of the formations are very singular and interesting to. study.

Mining is carried on to some extent near the lakes. The adjacent gulches and ravines are well worth a visit, which rarely fails to reward the explorer by the discovery of some strange and wonderful freak of nature. Here it is a remarkable formation of rock, there a rare mineral, and again the visitor sees how even the trees and the shrubs adapt themselves to the situation in which they are placed.

A short distance above the upper lake is a beautiful waterfall, where the clear water comes roaring and foaming down over a bed of boulders.

J. L. HARBour. 


\section{Signal Station on Pike's Peak.}

When the United States signal service, which most people call the weather bureau, although there is no warrant for so doing, was first established in November, 1870 , it was a very small affair, and even so late as 1873 it had not grown to very large proportions. In the summer of that year it was determined to establish stations on the summits of one or more of the peaks of the Rocky Mountains, and Pike's Peak was selected for the site of the first station.

There were several reasons for this choice. Along the eastern fringe of the mountains in Wyoming and Colorado there are at least a dozen isolated peaks, each about fourteen thousand feet in height, and as far as the climatic conditions were concerned, any one of them might have been chosen. But several of these peaks are almost inaccessible except to daring climbers, and others, although accessible even to horses, were too far from any inhabited point.

Pike's Peak was found, on examination, to be the most eligible, possessing peculiar advantages over all others. It is on the end of a spur of the range and overtops any peak within fifty miles. It is very easy of access, pack-mules and equestrians easily reaching the extreme summit.

The object of establishing the station on the summit of the peak was to study the constitution of the upper stratum of the atmosphere. A great many observations at heights varying from one to three miles above the sea have been made at different times and at different places by means of balloons, but such observations, although furnishing very interesting data, are of very little practical value.

Now Pike's Peak is two and three-quarters miles above the level of the sea, and observations taken there would be many and continuous.

It has been known for many years that there are upper 


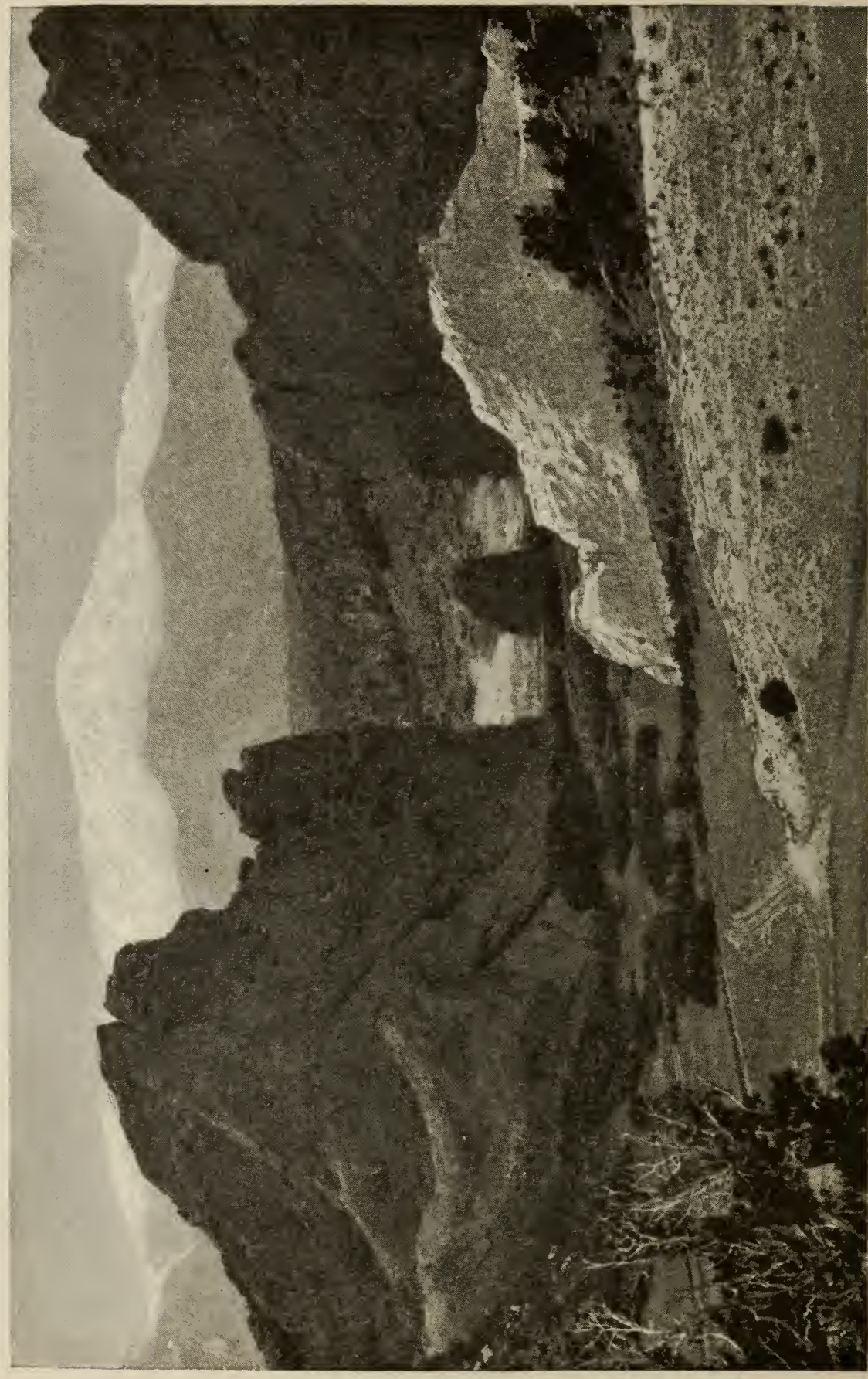

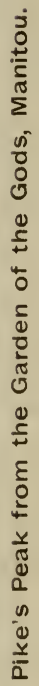


currents in the atmosphere moving generally from the West. This was determined by the balloon observations before alluded to, and by occasional observations taken on the tops of mountains, but more particularly by noting the drift of clouds, such as the cirrus variety, which prevail only in the upper regions. It was believed that the summit of the peak was high enough to be in this current.

Of course there were also many other problems, interesting and important, which it was hoped this station would solve.

The first step was to look at the ground, and in July two observers of the signal service were sent from Washington to Colorado Springs. Mr. George Boehmer, later of the Smithsonian Institute, was one, and I was the other. When we arrived at Colorado Springs we rented an office, and prepared for a trip to the summit.

There were two routes to the top of the peak. One steep and tiresome trail about nine miles in length led from Manitou, the celebrated watering-place, from which a railway to the top of the peak was completed in I89I. The other trail was much longer, across the foot-hills from Colorado Springs, up the Bear Creek Canon for eight or nine miles to Mystic Lake, thence through the timber and, above it, along the bare and rocky ground to the summit.

Boehmer and I started to walk up to the peak, taking with us a burro to carry our coats and some necessary camping supplies. It was a beautiful day, with such fresh and pure air as one meets with nowhere but in mountain regions, and we felt that we could walk to the summit with the greatest of ease.

That was our first mistake. Colorado Springs, our startingpoint, is about six thousand feet above the sea, or nearly as high as the summit of Mount Washington, the highest of the White Mountains, and you know that the air is more and more rarefied as you ascend above sea-level.

Our lungs were not used to this air, and we had hardly started before we were compelled to stop and rest. Indeed, 
the journey was a constant succession of rests, and it was high noon before we reached the mouth of Bear Creek Canon, where the real ascent begins.

From this point the way is up, up, without cessation. The trail was a mere foot-path, crossing and recrossing the shallow creek twenty-one times in eight miles, and for the entire distance hemmed in by lofty mountains from one to five thousand feet in height. It is a beautiful stretch of scenery.

It was quite dark before we reached the lake, which we afterwards called Mystic Lake, and camped for the night. This little sheet of water is only a few acres in area, and is as placid as glass, having no visible inlet or outlet. By a simple calculation with an aneroid barometer, we found the elevation of this lake to be about ten thousand feet above sea-level. That meant that we had over four thousand feet more to climb, and nearly five miles more to walk.

I shall certainly never forget this night, the first I had ever spent in the open air of the wilderness, although I had had some experience on Mount Washington in the spring. It seemed so far away from the rest of the world, the silence was so profound, the starry sky so sparkling, and the lowering mountains which surrounded the lake so massive and gloomy.

After awhile I fell asleep, and it seemed only about an hour before I was awakened by Boehmer and informed that it was two o'clock in the morning, and that if we wanted to see the sunrise from the peak we must lose no time. I was in favor of postponing the trip, but Boehmer, more enthusiastic, dragged me upon my feet, and away we went, stumbling up the steep path in the darkness. It was a toilsome journey.

Although it was in the month of July, it was excessively cold and raw, and we shivered and shook as we stood on the bleak summit and looked out toward the east, in which the day was beginning to break.

Above our heads the sky was clear and starlit; but beneath our feet, stretching out for a hundred miles, lay a bank of snowy clouds looking like a frozen ocean. Away 
off in the east a narrow rim of gold appeared, and when a handbreadth of the sun arose the ocean began to move. The billowy clouds gently rose and fell while athwart them the sun shot long arrows of gold and silver light. It was a gorgeous and impressive sight, but it did not last more than five minutes. The mass of clouds dissipated as the sun rose higher, and in an incredibly short space of time the sky was entirely clear.

The view was magnificent. In the west the great main range of the Rockies, two hundred miles away, loomed up with snowy heads; in the north lay Denver, seventy-five miles distant, while away beyond was a white speck which we knew to be Cheyenne, in Wyoming. In the south Pueblo lay on the plain, and almost at our feet Colorado Springs, in which it seemed as if we might have cast a stone, while away beyond stretched the great Colorado plains, with the Platte River winding through them like a silver thread.

The trip down to the Springs was made in a very short time, and by noon we were safe in our office, and completely prostrated. The report which we sent to the chief signal officer was truthful, but dispiriting. We were perfectly willing to go up on the peak and take observations, but how ? A house was necessary, and where was the house to come from? The chief signal officer, who knew nothing about the difficulties in the way, replied to the report by sending out three men, with directions for us five to build the house ourselves!

Fancy our predicament! Five men, not one of whom knew anything about building, all from the East, expected to go up into an altitude of fourteen thousand feet and build a house! It was a preposterous idea, but Boehmer, who was the observer-in-charge of the party, prepared to obey orders.

We purchased for each man one pick, one shovel, one trowel, one axe, one hammer, and then laid in a full camping outfit for the party, including a large A tent. The supplies and provisions loaded down five pack animals, and as each 
man was mounted we made quite a cavalcade as we started out on our foolish venture.

We travelled up the Bear Creek trail and pitched our camp in a canon just below timber-line, and about two miles from the peak, and the next day we lugged our tent up to the summit, and that was as near as we ever came to building the house. The chief signal officer had a vague sort of an idea that we might build a log house of some kind, not knowing that the timber was two miles away. We did build a $\log$ house, but it was in the canon where we had our camp, and it was a very substantial affair, but would not have answered at all for winter quarters.

Here we lived for a month or so, while Boehmer was explaining to the chief signal officer that it was an impossibility for us to build a log house, or indeed a house of any kind, on the summit in any time less than a year or two.

Finally, Lieutenant Jackson, the disbursing officer of the service, came out from Washington to see what the trouble was. He went up on the peak, looked at it about five minutes, and decided that the project was absurd. If the house was built at all, it must be by skilled mechanics. So a contract was given out to a builder in Denver, and the house was built inside of four or five weeks.

The daily routine of observations in the signal service at that time included seven observations of the instruments. The first observation had to be taken at about half-past five in the morning, and the last at nine o'clock in the evening. In addition to the observations, there was, of course, the usual amount of office work, but not more than enough to keep one man steadily employed.

The telegraph line was, however, our greatest trouble. It extended from Colorado Springs to the summit, following the trail to the timber-line, and then made a bee-line for the peak.

This line, erected by private contract, was of thin and inferior wire, and very poorly constructed. Trees were used for supports for the greatest part of the route, and they were 
continually falling down. Above the timber-line, the wire, being exposed to the air, would become encrusted with frost until it was fully six inches in diameter.

When the wind blew strongly, which was nearly an every-day occurrence, the wire would sway backward and forward until it snapped. The only way to obviate these breaks was to thoroughly insulate the wire and lay it on the ground. When the line broke some one had to go out and repair it, and the task generally fell to me. It was not only disagreeable, but dangerous.

The most disagreeable portion of our life was, of course, the monotony. No words can describe the loneliness of such a life; with the exception of ourselves, there was not a living thing in sight. Of plant life, even in summer, there was none, not a shrub or a speck of moss, and in the winter, when the entire mountain range was covered with snow, the scene was desolation itself.

Winter set in with the utmost rigor about the first of November, although even summer on the peak would have been called winter in other localities. Snow-storms were of almost daily occurrence, and the temperature fell steadily. By the tenth of November the thermometer touched zero, and from that time it was intensely cold. The wind began to blow with great velocity, fifty, sixty and seventy miles an hour. The cold and the snow were not so much to be dreaded, had it not been for the wind. When it was calm and clear, no matter how cold, we thought nothing of taking a stroll in our shirt-sleeves; but when the wind blew we could not put on enough wraps to keep out the cold.

Christmas week was very stormy, but we managed to celebrate the holidays by gorging ourselves rather more than usual. On New Year's day there began a storm of seven days' duration, and on the sixth day the telegraph line broke somewhere - where, we had no means of judging. After breakfast I started out to find the break, and repair it.

It was about ten degrees below zero when I started, a light 
snow falling and a brisk wind of twenty miles an hour blowing from the west. The temperature soon began to fall and the wind to blow a perfect gale. In mending the break, which occurred near the timber-line, I was obliged to remove my thick lamb's wool gloves, and when I replaced them I was painfully conscious that both hands were frozen.

On my way back to the peak I had a terrible struggle against the gale, and was nearly exhausted when I came in sight of the station. There the trail was very steep, and I went up literally on all fours. Staggering to the door, I fell into the room at full length in a swoon.

I did not lose my fingers, but my sphere of usefulness was over there, and in a short time I bade farewell to the peak. As a souvenir of my experience ${ }^{\circ}$ carried one of my hands in a sling for more than a year, the fingers of which tingle even now with each recurring winter.

JAMES H. SMiTH.

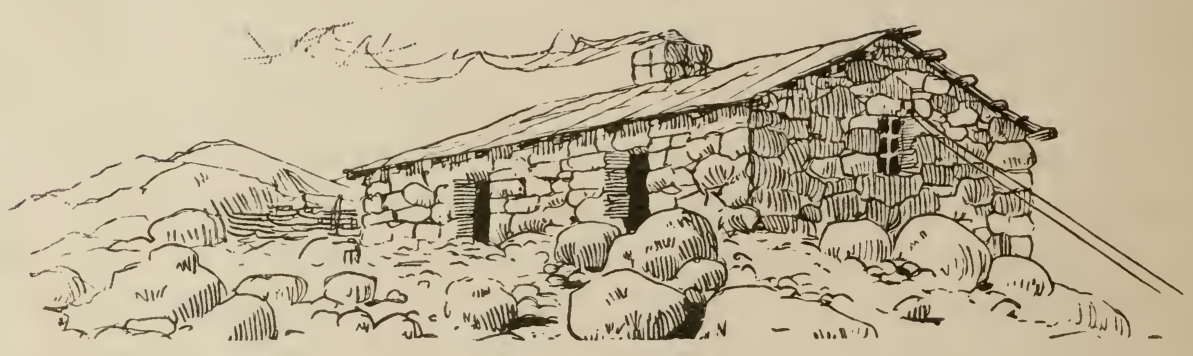


THE COMPANION SERIES

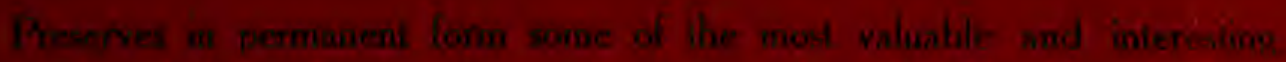

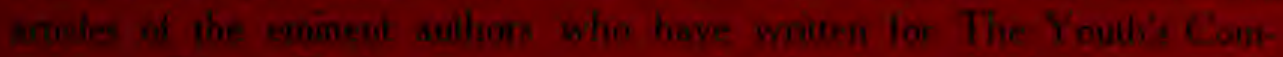

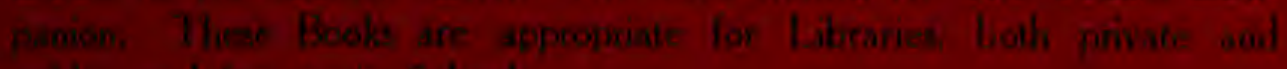
police. and for wine in Sh louts

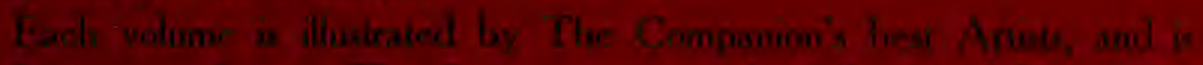

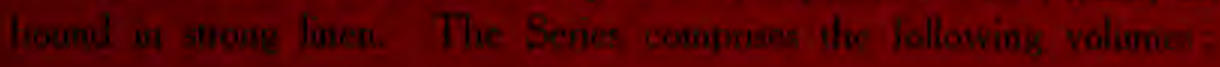

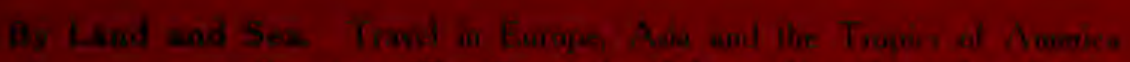

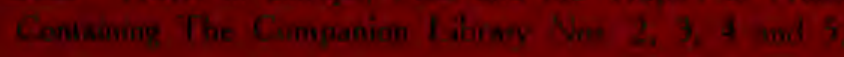

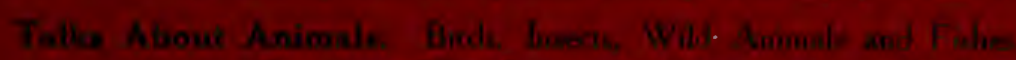

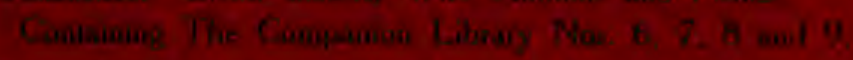

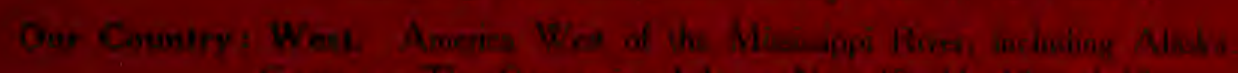

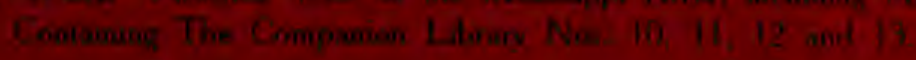

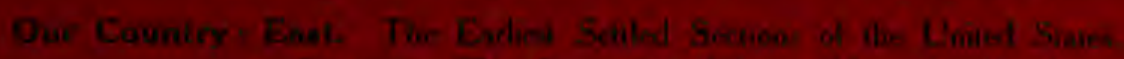

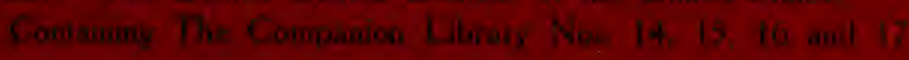

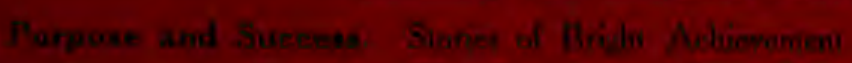

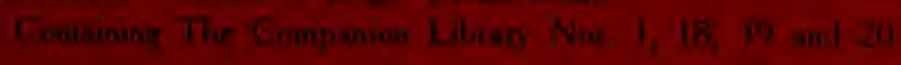

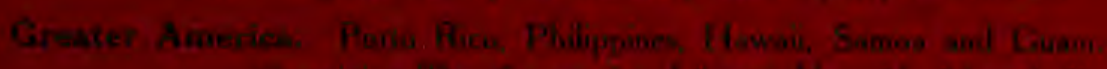

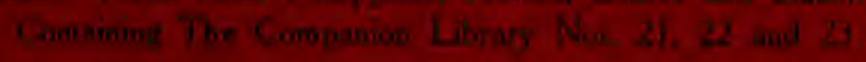

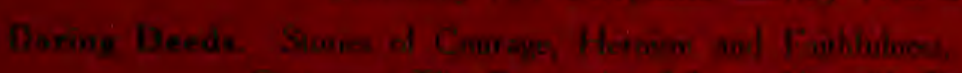

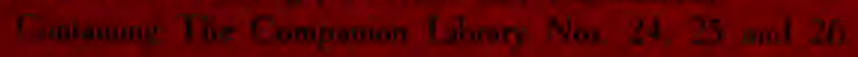

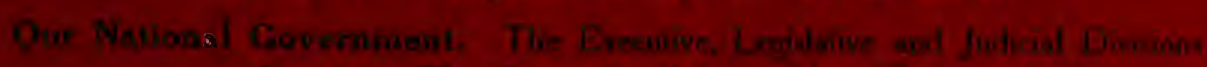

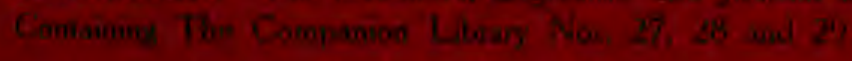

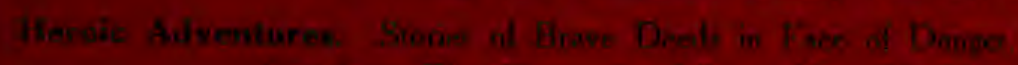

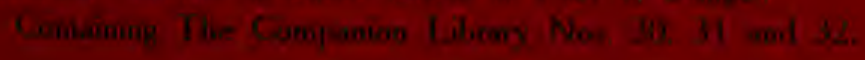

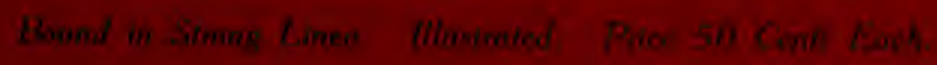

The Companion Classics.

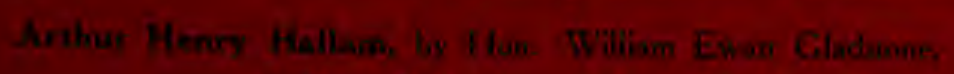
A Day Sixty Yen Ago, by Han Gere F Hon

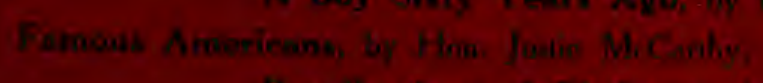

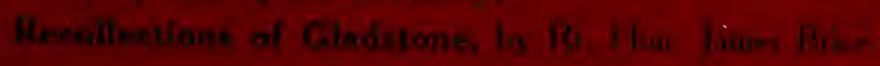

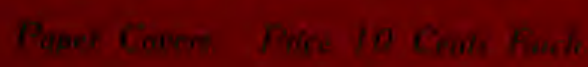


